\title{
ALGILANAN SOSYAL DESTEĞİN İŞE YABANCILAŞMA ÜZERİNDEKİ ETKİSINDE DOĞAL DAVRANIŞIN ARACILIK ROLÜ
}

\author{
MEDIATOR ROLE OF NATURAL BEHAVIOR IN THE EFFECT OF \\ PERCEIVED SOCIAL SUPPORT ON WORK ALIENATION
}

\author{
Selçuk YEKE ${ }^{* *}$ \\ İbrahim PINAR ${ }^{* * *}$ (ID)
}

\section{Öz}

$\mathrm{Bu}$ çalışma algılanan sosyal desteğin işe yabancılaşma üzerindeki etkisinde doğal davranışın aracılık rolü üstlenip üstlenmediğini belirlemek üzere gerçekleştirilmiştir. Araştırmanın modeli doğrultusunda algılanan sosyal desteğin işe yabancılaşma üzerinde negatif yönde anlamlı bir etkisinin olacağı kurgulanmış, ancak bu etkinin esasında doğal davranıştan dolayı ortaya çıkabileceği ileri sürülmüştür. Araştırmanın modelini destekleyecek şekilde literatür taraması yapılmış ve ilgili çalışmaların sonuçlarına yer verilmiştir. Araştırma kapsamında İstanbul'da faaliyet gösteren vakıf ve özel mevduat bankalarında görev yapan 376 gişe/operasyon çalışanından anket yoluyla veri toplanmıștır. 5'li likert ölçeği kullanılmış ve toplam 40 soru katılımcılara yöneltilmiştir. Aracılık analizinden önce ölçeklere ilişkin geçerlilik ve güvenilirlik analizleri AMOS programıyla gerçekleştirilmiştir. Ölçeklerin geçerliliği ve güvenilirliği ortaya konulduktan sonra aracılık analizi SPSS PROCESS V3.2 makro programıyla gerçekleştirilmiştir. Yapılan aracılık analizi sonucunda algılanan sosyal desteğin işe yabancılaşma üzerindeki etkisinde doğal davranışın aracılık rolü ortaya çımıştır. Dolayısıyla algılanan sosyal desteğin işe yabancılaşmayı azaltıcı bir etkisi olmakla birlikte, esasında bu etkinin doğal davranıştan kaynaklandığı ortaya çıkmıştır.

Anahtar Kelimeler: İşe yabancılaşma, algılanan sosyal destek, doğal davranış

JEL Sinıflamasi: M10, D23, M19

* Bu çalışma Selçuk YEKE tarafından Prof. Dr. İbrahim PINAR danışmanlı̆̆ında hazırlanan "İşe Yabancılaşmada Algılanan Sosyal Destek ve Duygusal Zekâ: Duygusal Emek Kuramı Boyutlarının Aracılık Rolü Üzerine Bir Araştırma” konulu doktora tezinden türetilmiştir. Bu araştırmanın verileri 2020 yılından önce toplandığı için Etik Kurul iznine ihtiyaç duyulmamıştır.

** Sorumlu Yazar: Arş. Gör. Dr, Ardahan Üniversitesi İ.İ.B.F, selcukyeke@ardahan.edu.tr, ORCID: 0000-0002-1953-6222

*** Prof. Dr, İstanbul Üniversitesi İşletme Fakültesi, ipinar@istanbul.edu.tr, ORCID: 0000-0003-1057-3358

Bu makaleyi alıntılamak için: Yeke, S. \& Pınar, İ. (2021). Algılanan Sosyal Desteğin İșe Yabancılaşma Üzerindeki Etkisinde Doğal Davranışın Aracılık Rolü. Journal of Research in Business, 6(1), 222-249. 


\begin{abstract}
This study was carried out to determine whether natural behavior has a mediating role in the effect of perceived social support on work alienation. In line with the model of the research, it has been builted that perceived social support is be able to have a significant negative effect on work alienation, but it has been suggested that this effect may actually occur due to natural behavior. Within the scope of the research, data were collected from 376 operation employees working in foundation and private deposit banks operating in Istanbul. 5-point Likert scale was used, and 40 questions in total were asked to participants. Before the mediation analysis, validity and reliability analyses of the scales were carried out with the AMOS program. After the validity and reliability of the scales were demonstrated, mediation analysis was performed with the SPSS PROCESS V3.2 macro program. As a result of the mediation analysis, mediating role of natural behavior has revealed in the effect of perceived social support on work alienation. Therefore, although perceived social support has an effect on reducing work alienation, it has been revealed that this effect actually derived from natural behavior.
\end{abstract}

Key Words: Work alienation, perceived social support, natural behavior

JEL Classification: M10, D23, M19

\title{
Extended Summary
}

In this study, it was investigated whether natural behavior plays a mediating role in the effect of perveived social support, which is an organizational and social factor, on work alienation. As a result of literature review, it is expressed that there are many factors that affect work alienation, and one of these factors is social support that employees get from work environment. It was stated that when employees can get social support from work environment, their negative attitudes towards the work will decrease, and they will not be alienated from work environment. However, it is very crucial in this process to reflect the emotions and behaviors of employees comfortably and naturally. In fact, if the emotions and behaviors of employees are limited and the necessity of the rules of showing emotions towards customers arise, the level of stress and tension of employees might increase. In this case, even if employees receive social support from work environment, they might be alienated from the work. Although the social support that employees get from the work environment is effective in reducing work alienation, the natural behaviors of employees and the low stress level might come to the forefront as the main factor in this decrease. In order to investigate this situation, data were collected from 376 operation employees working in foundation and private deposit banks operating in Istanbul through questionnaire. 5-point Likert scale was used, and 40 questions in total were asked to participants. Operation employees are among the group likely to receive social support from their colleagues for their work. Moreover, intense work tempo in the sector, difficulties in customer relations, and high risk of the sector can cause employees to develop a negative attitude towards the work. For these reasons, the sample of the research consisted of operation employees. As a result of analyzing the collected data, it has been revealed that perceived social support has a significant negative effect on work alienation. Also, it has been confirmed that natural behavior plays a mediating role in the effect of perceived social support on work alienaton. 


\section{Giriş}

İşletmeler yaşamını sürdürebilmesi için iç ve dış çevrede birtakım kaynaklara ihtiyaç duymaktadır. $\mathrm{Bu}$ kaynaklar temin edilerek işletmeler amaç ve hedeflerine ulaşabilmek için gerekli stratejilerini oluşturmaktadır. İç çevrede önemli kaynaklardan birisi olan işgücü işletmelerin hazırladığı stratejilerini uygulamak açısından son derece önemli olmakla birlikte, işgücünün motivasyonu ve işe bağlılı̆̆ verimlilik ve etkinlik açısından kritik bir önem taşımaktadır. Bu hususta işletme çalışanlarının işe karşı tutumu üst yönetimi etkileyen bir faktör olarak ele alınmaktadır. Çalışanların istek ve talepleri karşılanmadığında, çok fazla iş yükü ile karşılaştığında ve değer verildiğini hissetmediklerinde işe karşı yabancılaşma duygusu ortaya çıkabilmektedir. Bu durumda çalışanlar işe karşı olumsuz bir tutum sergileyerek işten uzaklaşmaktadır. Çalışanların iş çevresinden elde edebileceği sosyal destek işten uzaklaşmalarını engelleyebilecek bir faktör olarak ortaya çıkmaktadır. Çalışanların iş arkadaşlarından ve yöneticisinden sosyal destek görmesi durumunda işe bağlılığının artabileceği ve işe karşı olumsuz tutum sergilemeyeceği öngörülmektedir. Dolayısıyla iş çevresinden elde edilen sosyal desteğin işe karşı tutumda değişimler meydana getirebileceği düşünülmektedir. Çalışanların algıladı̆̆ı sosyal desteğin işe yabancılaşmayı azaltabileceğine yönelik literatürde çalışmalar da mevcuttur. Bu çalışmada da algılanan sosyal destek ve işe yabancılaşma ilişkisi ele alınmakla birlikte, diğer çalışmalardan farklı olarak çalışanların sergileyeceği davranışın içeriğin ve özelliği de araştırma kapsamında değerlendirilmiştir. Algılanan sosyal desteğin işe yabancılaşmayı azaltması literatür doğrultusunda beklenebilecek bir bulgu iken, bu bulgunun esasında çalışanların işyerinde doğal ve samimi davranış sergilemesi sonucunda ortaya çıkıp çıkmadı̆̆ı bu araştırma çerçevesinde tartışılmıştır. Literatürde yer alan akademik çalışmalara göre çalışanların müşterilerle kurduğu ilişkilerde yaşadığı duygu ve davranışların işe yabancılaşma üzerinde etkili olabileceği söylenebilmektedir. Hem örgütsel hem de kişisel bir faktör olabilecek doğal davranışın işe yabancılaşmayı açıklamada önemli bir referans olabileceği tahmin edilmektedir. Çalışanların müşterilere karşı doğal ve samimi duygularını yansıtması durumunda işe karşı tutumda değişimler meydana gelebilmektedir. Bu doğrultuda çalışanların algıladığı sosyal destek ile sergileyeceği doğal davranışın işe yabancılaşma üzerinde etkili olabileceğine yönelik bir sav ortaya konulabilmektedir. Kavramsal çerçeve temelinde araştırma modeli oluşturulmuş ve işe yabancılaşma, algılanan sosyal destek ve doğal davranış arasındaki ilişkiler incelenmiştir.

\section{Teorik Çerçeve ve Hipotezlerin Oluşturulması}

İnsan davranışının ve gelişiminin anlaşılabilmesi bakımından kişiden kaynaklı faktörler ele alınmakla birlikte insanın sosyal ilişkilerinin ve elde ettiği sosyal desteğin de incelenmesi gerektiği vurgulanmaktadır. Kişinin çevresine karşı uyumu ve gelişimi için kişinin ailesi, arkadaşları, sosyal çevresi ve sosyal destek sağlayan diğer faktörlerin rolü ön plana çıkmaktadır (Yıldırım, 1997). Kişiler çevresinden gelebilecek olan desteği sübjektif bir şekilde değerlendirmektedir. Buna göre kişilerin algıladığ sosyal destek, kişilerin arzu ettiği zaman çevreden desteğin gelebileceğine ve bu desteğe ulaşabileceğine yönelik algısını ifade etmektedir (Kitamura, Kijima, Watanabe, Takezakii, \& Tanaka, 1999). Algılanan sosyal destek esasında insanlar arasında etkileşimin olup olmadığına 
yönelik kişi tarafından yapılan değerlendirmeyi içermektedir. Etkileşim olduğunda bu etkileşimin süresi ve yapısı yine kişi tarafından değerlendirilmektedir. Bununla birlikte kişi ile farklı gruplar arasındaki ilişkinin yardımsever temel üzerine kurulup kurulmadığı da algılanan sosyal destek kapsamında incelenmektedir (Schaefer, Coyne \& Lazarus, 1981). Araştırma kapsamında ele alınan diğer bir değişken işe yabancılaşma ise, bir insanın iş ortamından ilişkisini kesmesi ve iş ortamından uzaklaşması olarak ifade edilmektedir (Hirschfeld \& Field, 2000). Bir başka deyişle işe yabancılaşma, kişinin üstlendiği işi yaparken kendi kontrolü dışındaki unsurlar tarafından etkilenerek yetkisizlik hissine kapılması olarak açıklanmaktadır (Pearlin, 1962). Çalışanların işyerinde daha az kontrole sahip olması ve önemli düzeyde yetenek gerektirmeyen işleri yerine getirmesi durumunda işe yabancılaşma duygusunun ortaya çıkabileceği ifade edilmektedir (Greenberg \& Grunberg, 1995). İşe yabancılaşmanın esasında iş kapsamında veya işten bağımsız şekilde çalışma ortamında oluşturulan sosyal ilişkilerde ve kişinin kendi iç dünyasında yaşadığı psikolojik bir çözülme ve uzaklaşma durumu olduğu söylenmektedir (Banai \& Reisel, 2007). İşe yabancılaşma aynı zamanda çalışanlarla ve çalışanların yaptıkları işle ilgili yanlış beklentilerin oluşturulması, çalışanlardan beklenen rollerin birbiriyle çelişkili olması, çalışanların kontrol gücünün olmaması ve ağır iş yükünden dolayı çalışanların yakın çevresine zaman ayıramamasıyla birlikte işyerine yönelik ilginin ortadan kalkmasını ifade etmektedir. İşe yönelik yanlış beklentilerin meydana gelmesi ve çalışanlar arasında eşit muamelenin yapılmaması yabancılaşma duygusunun yaşanmasına neden olabilmektedir. Çalışanlardan beklenen rollerin birbiriyle çelişkili olması yine yabancılaşma duygusunu ortaya çıkarabilmektedir. Çalışanların kendi sorumluluğundaki işleri kontrol edememesi durumunda çalışanlar kendilerini güçsüz hissedebilmekte ve yabancılaşma duygusunu yaşayabilmektedir. Bununla birlikte çalışanların uzun süre boyunca işyerinde bulunması ve yöneticilerin çok daha fazla iş talebinde bulunması çalışanların yakın çevresiyle zaman geçirmesini engellemektedir. Bu durum yine çalışanların yabancılaşma duygusunu yaşamasına neden olabilmektedir (Korman, WittigBerman \& Lang, 1981).

Çalışanların diğer çalışanlar ile anlamlı ilişkiler kuramaması ve sosyal bağlantılarının olmaması işe yabancılaşmayı ortaya çıkaran bir faktör olarak düşünülmektedir (Shantz, Alfes, Bailey \& Soane 2015). İşyerinde soyutlanma ve dışlanma yaşayan çalışanlar rahatlıkla ulaşabileceği birilerini bulması, onlarla paylaşımlarda bulunması ve alacağı kararlarda gerekli desteği alması durumunda kendilerini daha güçlü hissetmektedir (Halis \& Demirel, 2016). Bu durumda algılanan sosyal desteğin işe yabancılaşmanın önüne geçmek ve çalışanların iş performansını artırmak için önemli olduğu düşünülmektedir. Çalışanların işletme yönetiminin ve çevresindeki insanların desteğinin önemini kavrayarak, işletme dışında ve mesai saatleri dışında çalışma arkadaşlarıyla bir araya gelmesi ve sosyal etkinliklere katılması durumunda iş performansının artacağı ileri sürülmektedir (Tekingündüz, Kurtuldu \& Eğilmez, 2016). Literatürde yer alan algılanan sosyal destek ile işe yabancılaşma arasındaki ilişkiyi belirlemeye yönelik çalışmalar incelendiğinde algılanan sosyal desteğin işe yabancılaşma üzerinde etkili olduğuna yönelik sonuçlar elde edilmiştir. Nair \& Vohra (2010), bilgi işçilerinin işe yabancılaşmalarına yol açan faktörleri belirlemeye yönelik gerçekleştirdiği çalışmada sosyal destek ile işe yabancılaşma arasında anlamlı bir ilişki ortaya çıkmıştır. Araştırma kapsamında Hindistan'da bilgi işlem endüstrisinde faaliyet gösteren büyük, orta ve küçük ölçekli şirketlerde görev yapan 1142 
bilgi işçisinden veri toplanmıştır. Yapılan analizler sonucunda işletme içindeki sosyal ilişkilerden elde edilen tatmin düzeyi ile işe yabancılaşma arasında anlamlı ve negatif bir ilişkinin ortaya çıktığı tespit edilmiştir. Mottaz (1981), işe yabancılaşmaya yol açan sosyal faktörleri incelemeye yönelik başka bir çalışma gerçekleștirmiştir. Araştırma kapsamında yedi farklı iş alanında görev yapan çalışanlardan anket yoluyla veri toplanmıştır. Bu doğrultuda 169 üniversite personeli, 108 ilkokul öğretmeni, 112 sekretarya çalışanı, 167 polis amiri, 440 polis memuru, 68 ustabaşı ve 249 fabrika işçisi olmak üzere araştırmanın toplam örneklemi 1313 çalışandan oluşmaktadır. Yapılan analizler sonucunda yönetici ve iş arkadaşları desteğinin eksikliği ile işe yabancılaşmanın güçsüzlük, anlamsızlık ve kendine yabancılaşma boyutları arasında pozitif bir ilişkinin olduğu tespit edilmiştir. Pearlin (1962), işe yabancılaşmayı incelemeye yönelik bir çalışma gerçekleştirmiştir. Çalışmada, işletmelerdeki yetki biçimi, çalışanların mesleki başarısı, ödül beklentisi ve sosyal çevresi ile işe yabancılaşma arasındaki ilişkiler ele alınmıştır. Araştırmanın kapsamını Saint Elizabeths hastanesinde görev yapan hemşireler oluşturmaktadır. Bu doğrultuda Saint Elizabeths hastanesinde görev yapan 1138 hemşireden anket yoluyla veri toplanmıştır. Yapılan analizler sonucunda hastane servislerinde veya bölümlerinde arkadaşı olmayan ve bu doğrultuda başkalarıyla sosyal ilişkileri bulunmayan hemşirelerin işe karşı yabancılaştıkları ortaya çıkmıştır. Algılanan sosyal destek ile işe yabancılaşma arasındaki ilişkiyi incelemeye yönelik yapılan çalışmalar incelendiğinde algılanan sosyal destek ile işe yabancılaşma arasında pozitif bir ilişkinin olduğu görülmektedir.

Araştırmanın aracı değişkeni olan doğal davranış duygusal emeğin boyutlarından birini oluşturmaktadır (Ashforth \& Humphrey, 1993). Duygusal emek özellikle hizmet sektöründe gerçekleşmekte olup, çalı̧şanların duygularını düzenleyebilmesine yönelik bir bakış açısı sunmaktadır. Hizmet sunan çalışanların duygusal tepkilerini müşteri memnuniyeti oluşturacak şekilde düzenlemesi beklenmektedir. Çalışanlar aldıkları ücretin karşıllı̆ında kendi duygularını düzenlemekte ve aynı zamanda karşı tarafın da duygularını yönlendirmektedir. Duygusal emek kavramının çıkış noktasını da tam olarak bu olgu oluşturmaktadır. Bu durumda müşterilerle iletişim kuran çalışanların duygularını organizasyon tarafından belirlenen kurallara uygun hale getirmesi gerekmektedir (Oral \& Köse, 2011). Çalışanların duygusal süreçleri müşterilerle kurduğu ilişki esnasında gerçekleşmektedir. Çalışanlar müşterilerde duygusal bir durum oluşturmak için kendi duygularını bastırmaktadır. Bu süreçte üst yönetimin ilgisi çalışanların müşterilere karşı gösterdiği duygular üzerine yoğunlaşmaktadır. Dolayısıyla duyguların çalışanlar tarafından nasıl yönlendirildiği veya düzenlendiği üst yönetim açısından önem kazanmaktadır (Seçer, 2010). Duygusal emeğin boyutlarından birisi olan doğal davranış ise çalışanların müşterilere karşı duygularını samimi ve spontane bir şekilde göstermesini ifade etmektedir. Hizmet sektöründe görev yapan çalışanlar kendilerinden beklenen duyguları değiştirmeye ve şekillendirmeye çalışmaksızın doğal bir şekilde yansıtabilmektedir. Örnek olarak, yaralı bir çocuğa müdahale eden bir hemşire çocuğa karşı rol yapma ihtiyacı duymamakta ve samimi bir şekilde yaklaşmaktadır. Bu doğrultuda çalışanlar kendilerinden beklenen duyguları gerçek ve samimi bir şekilde sergileyebilmektedir (Ashforth \& Humphrey, 1993). Müşterilere karşı duygularını doğal ve samimi bir şekilde yansıtan çalışanlar üst yönetim tarafından belirlenen duygu gösterim kurallarına uyabilmek için duygularını şekillendirmeye gerek duymamaktadır (Wu, Shie \& Gordon, 2017). Yansıtılan duyguların da genel 
olarak işletmeler tarafından arzu edilen duygu gösterim kurallarıyla örtüştüğü ifade edilmektedir (Peart, Roan \& Ashkanasy, 2012). Bu durumda çalışanlar üst yönetim tarafından hiçbir baskı görmeden veya sebep dayatılmadan müşterilere karşı doğal bir şekilde yaklaşmakta ve gerçek duygularını ortaya koymaktadır (Işık \& Hamurcu, 2017). Çalışanların müşterilere karşı duygularını doğal ve samimi bir şekilde yansıtması sürecinde iş ortamından elde ettiği sosyal desteğin önemli olduğu ifade edilmektedir. Çalışanlar işletme tarafından kendilerine sosyal destek sağlandığını düşündüğünde işletmenin hedeflerine ulaşabilmesi için özverili şekilde çalışarak hiçbir fedakârlıktan kaçınmamaktadır. Çalışanlar bu doğrultuda kendilerinden beklenen duyguları doğal ve samimi bir şekilde içselleştirmektedir (Hur, Moon \& Jun, 2013). Sosyal desteğin gerçekleştiği iş ortamı çalışanlara duygularını müşterilere uygun bir şekilde yansıtması için gerekli imkânı sağlayarak çalışanların duygularını bastırma ihtiyacını azaltmaktadır (Mikeska, Hamwi, Friend, Rutherford \& Park, 2015). Özellikle yöneticiler tarafından çalışanlara verilen sosyal destek çalışanların duygu gösterim kurallarını daha fazla içselleştirmesini sağlamaktadır. Bu şekilde gerçek ve samimi olmayan duygular daha az kullanılarak çalışanların performansının artırılması hedeflenmektedir (Kim, Hur, Moon, \& Jun, 2017). Algılanan sosyal desteğin doğal davranışı artırabileceğine yönelik bilimsel çalışmalar literatürde yer almaktadır. Lee, Hung \& Huang (2012) gerçekleştirdiği çalışmada iş tatmini ile organizasyon tarafından sağlanan desteğin duygusal emek üzerindeki etkisini araştırmıştır. Araştırmanın örneklemini Tayvan'da faaliyet gösteren 105 üniversite ve 44 kolej olmak üzere toplam 149 eğitim kurumundaki halkla ilişkiler bölümünde görev yapan çalışanlar oluşturmaktadır. Araştırma yöntemi olarak anketten yararlanılmıştır. Yapılan analizlerin sonucunda, organizasyon tarafından sağlanan sosyal desteğin doğal davranış üzerinde düşük düzeyde pozitif ve anlamlı bir etkiye sahip olduğu tespit edilmiștir. Oktuğ (2013), organizasyon tarafından sağlanan destek ile duygusal emek arasındaki ilişkide algılanan örgütsel prestijin düzenleyici etkisine yönelik bir çalışma gerçekleştirmiştir. Araştırmanın kapsamını İstanbul'un Avrupa yakasında faaliyet gösteren alışveriş merkezlerinin hazır giyim mağazalarında çalışan satış elemanları oluşturmaktadır. Bu doğrultuda 20 alışveriş merkezinde bulunan hazır giyim mağazalarında çalışan 210 satış elemanından anket yoluyla veri toplanmıştır. Yapılan analizlerin sonucunda, organizasyon tarafından sağlanan destek ile doğal davranış arasında orta düzeyde pozitif ve anlamlı bir ilişki tespit edilmiştir. Gülaydın (2019), organizasyon tarafından sağlanan destek ile duygusal emek arasındaki ilişkiyi belirlemeye yönelik bir çalışma gerçekleştirmiştir. Araştırmanın kapsamını Afyonkarahisar'da faaliyet gösteren beş yıldızlı otel işletmelerinin çalışanları oluşturmaktadır. Bu doğrultuda toplam 544 otel çalışanından anket yoluyla veri toplanmıştır. Yapılan analizlerin sonucunda, organizasyon tarafından sağlanan destek ile doğal davranış arasında orta düzeyde pozitif ve anlamlı bir ilişki bulunmuştur. Gülova, Palamutçuoğlu \& Palamutçuoğlu (2013) duygusal emek ile işe bağlllık arasındaki ilişkide amir desteğinin rolünü belirlemeye yönelik gerçekleştirdiği çalı̧̧mada amirin sağladığı sosyal destek ile doğal davranış arasındaki ilişki de araştırılmıştır. Ege Üniversitesi, Dokuz Eylül Üniversitesi ve Celal Bayar Üniversitesinin öğrenci işlerinde görev yapan 127 personelin örneklemi oluşturduğu bu çalışmada, amirin çalışanlara sağladığı sosyal destek ile doğal davranış arasında düşük düzeyde pozitif ve anlamlı bir ilişki bulunmuştur. Algılanan sosyal destek ile doğal davranış arasındaki ilişkiyi belirlemeye yönelik yapılan çalışmalar incelendiğinde, algılanan sosyal destek ile doğal davranış arasında pozitif bir ilişkinin olduğu görülmektedir. 
Çalışanların duygularını doğal ve samimi bir şekilde yansıtarak performansını artırmasıyla birlikte işe karşı yabancılaşmayacağı ileri sürülmektedir. Bu durumda doğal davranış ile işe yabancılaşma arasında negatif bir korelasyon olabileceği ileri sürülmektedir (Begenirbaş, 2015). Doğal davranışın işe yabancılaşmayı azaltabileceğine yönelik bilimsel çalışmalar da literatürde yer almaktadır. Aslan \& Mert (2019), duygusal emek ile işe yabancılaşma ilişkisinde psikolojik sermayenin düzenleyici etkisini belirlemeye yönelik gerçekleştirdiği çalışmasında samimi davranış ile işe yabancılaşma arasındaki ilişkiyi de incelemiştir. Araştırma kapsamında Gaziantep, Adana ve Osmaniye illerinde faaliyet gösteren dört ve beş yıldızlı otel işletmelerindeki 549 çalışandan anket yoluyla elde edilen veriler doğrultusunda analizler gerçekleştirilmiştir. Yapılan analizler sonucunda samimi davranışın işe yabancılaşma üzerinde düşük düzeyde negatif ve anlamlı bir etkisinin olduğu ortaya çımıştır. Kökden \& Işık (2018), duygusal emek ile işe yabancılaşma arasındaki ilişkiyi incelemeye yönelik bir çalışma gerçekleştirmiştir. Araştırmanın kapsamını Antalya ilinde faaliyet gösteren özel bankaların çalışanları oluşturmaktadır. Bu doğrultuda toplam 554 banka çalışanından anket yoluyla veri toplanmıştır. Elde edilen verilere dayanarak yapılan analizler sonucunda samimi davranış ile işe yabancılaşma arasında düşük düzeyde negatif ve anlamlı bir ilişki tespit edilmiştir. Begenirbaş (2015), psikolojik sermayenin çalışanların duygu gösterimi ve işe yabancılaşmasına etkilerini ortaya koymaya yönelik bir çalışma gerçekleştirmiştir. Bu çalışmada doğal davranış ile işe yabancılaşma arasındaki ilişki de ele alınmıştır. Araştırmanın kapsamını Ankara’da kamu ve özel hastane ve tıp merkezleri ile aile sağllğı merkezlerinde (sağlık ocakları) doktor, hemşire ve sağlık teknisyeni (laboratuvar, radyoloji, vb.) olarak yalnızca hastalarla ilgili birimlerde görev yapan sağlık çalışanları oluşturmaktadır. Bu doğrultuda toplam 187 sağlık sektörü çalışanından anket yoluyla veri toplanmıştır. Elde edilen veriler ışığında yapılan analizlerin sonucunda, doğal davranış ile işe yabancılaşma arasında düşük düzeyde negatif ve anlamlı bir ilişki tespit edilmiştir. Köse (2019), duygusal emeğin hizmet kalitesi ve işe yabancllaşma üzerindeki etkisini incelemeye yönelik bir çalışma gerçekleştirmiştir. Araştırmanın kapsamını Türkiye’nin önde gelen sağlık grubunun İstanbul ilinde faaliyet gösteren, A sınıfı özel bir hastanesinde görev yapan sağlık çalışanları oluşturmaktadır. Kolayda örnekleme yoluyla hasta ve hasta yakınlarıyla etkileşim halinde bulunan bölümlerde görev yapan 207 sağlık çalşanından anket yoluyla veriler toplanmıştır. Elde edilen verilere dayanarak yapılan analizler sonucunda samimi davranışın işe yabancılaşma üzerinde düşük düzeyde negatif ve anlamlı bir etkisinin olduğu ortaya çıkmıştır. Doğal davranış ile işe yabancılaşma arasındaki ilişkiyi belirlemeye yönelik yapılan çalışmalar incelendiğinde, doğal davranış ile işe yabancılaşma arasında negatif bir ilişkinin olduğu söylenebilmektedir.

Açıklanan kavramsal çerçeve doğrultusunda, iş çevresinden aldığ 1 sosyal destek ile işini istekli şekilde yapmaya gayret eden çalışanların müşterilerin olumsuz duygularından etkilenmemek ve müşterilerle kurulan iletişim neticesinde meydana gelebilecek stresi yaşamamak için sergiledikleri doğal ve samimi davranışın işe karşı yabancılaşmanın önüne geçilmesinde önemli olduğu söylenebilmektedir. Buna göre, iş çevresinden sosyal destek gören çalışanlarda işe karşı yabancılaşma algısının azalabileceği, ancak çalışanlar tarafından doğal ve samimi davranışs sergilenmediği sürece yaşanabilecek stresten kaynaklı olarak bu azalışın gerçekleşmeyebileceği düşünülmektedir. Bu doğrultuda oluşturulan hipotez şu şekildedir: 
$\mathbf{H}_{1}$ : Algılanan sosyal destek ile işe yabancılaşma arasındaki ilişkide doğal davranışın aracılık rolü vardir.

\section{Metodoloji}

\subsection{Araştırmanın Amacı, Yöntemi ve Kapsamı}

Algılanan sosyal desteğin işe yabancılaşma üzerindeki etkisinde doğal davranışın aracılık rolünün araştırılması araştırmanın amacını oluşturmaktadır. Bu ilişkiye göre algılanan sosyal desteğin işe yabancılaşmayı azaltabileceği ancak bu azalışın esasında çalışanların doğal davranış sergilemesinden kaynaklanabileceği öngörülmektedir. Dolayısıyla doğal davranışın algılanan sosyal destek ile işe yabancılaşma arasındaki ilişkide etkin bir rol oynayıp oynamadığı irdelenmiştir.

Araştırmanın ana kütlesini İstanbul'da faaliyet gösteren kamu ve özel mevduat bankalarında görev yapan gişe/operasyon çalışanları oluşturmaktadır. Türkiye'de TBB’nin 2019 Mart ayında hazırladığı rapora göre toplam 34 mevduat bankası bulunmaktadır. Bu bankaların 3'ü kamu sermayeli, 9'u özel sermayeli, 21'i yabanc1 sermayeli ve 1'i ise tasarruf mevduat sigorta fonuna devreden bankadan oluşmaktadır. Bu bankalara ait toplam şube sayısı 10,355 iken, İstanbul'da faaliyet gösteren şube sayıları ise 2,729'dur. Türkiye genelinde devlet ve özel mevduat bankalarında toplam 185,581 personel görev yapmaktadır. Şube başına düşen çalışan sayısı ise 18'dir (www.tbb.org.tr; TBB Mart Raporu, 2019). İstanbul'da görev yapan personel sayısına ise ulaşılamamıştır.

Bankacılık sektöründe dijitalleşme ve verimlilik çalışmaları neticesinde şube başına düşen çalışan sayısında azalmanın meydana geldiği belirtilmektedir. Örnek olarak, 2018 verilerine dayanarak Vakıfbank’’n son 10 yılda şube başına düşen çalışan sayısında 6-7 kişilik tasarrufa gittiği ifade edilmektedir. Aynı şekilde yine 2018 verilerine dayanarak Ziraat Bankası’nın son 10 yılda 3 kişilik, Garanti Bankası'nın ise 4-5 kişilik tasarruf gerçekleştirdiği belirtilmektedir. Bunun yanında bankaların genel müdürlükleri şubeler için satış odaklı görevler belirlemektedir. Şubelerin en kritik görevinin hedef kitlelerine uygun yeni müşteriler kazanmak ve mevcut müşterilere yönelik çapraz satışları artırmak olduğu ifade edilmektedir. Bu doğrultuda şubelerin pazarlama faaliyetlerine ağırlık verdiği ve verimlilik adına operasyonel faaliyetleri azalttığı belirtilmektedir (www.capital.com). Bankacılık sektöründeki dijitalleşme çalışmaları ve şubelerin pazarlama faaliyetlerine verdiği önem göz önüne alındığında, şubelerde ortalama 4 gişe/operasyon çalışanının görev yaptığı varsayılmaktadır. Buna göre ana kütlenin ortalama 10,916 gişe/operasyon çalışanından oluştuğu söylenebilmektedir. Yapılan örneklem hesabına göre ise en az 371 gișe/operasyon çalışanından veri toplanması gerektiği sonucuna ulaşılmıştır. Bu doğrultuda kolayda örnekleme yöntemi benimsenmiş ve toplam 376 gişe/operasyon çalışanından anket yoluyla veri elde edilmiştir. Araştırmanın verileri 2019 yılında toplandığından dolayı Etik Kurul iznine tabi tutulmamıştır.

Anket 5'li Likert tipi ölçekten oluşmaktadır. Ankette algılanan sosyal desteğe ilişkin 16 ifade, işe yabancılaşmaya ilişkin 21 ifade ve doğal davranışa ilişkin 3 ifade bulunmaktadır. Algılanan sosyal 
destek, işe yabancılaşma ve doğal davranışı ölçen sorularla birlikte cinsiyet, yaş, kurumda çalışılan süre, toplam çalışlan süre gibi demografik sorular da ankette yer almaktadır. Gişe/operasyon çalışanlarının yaptıkları iş rutin, monoton, yaratıcılık gerektirmeyen ve devamlı kontrol gerektiren bir yapıya sahip olması, müşterilerle kurulan ilişkilerin ve bankacılık faaliyetlerin stres yaratması sebebiyle çalışanların işe karşı yabancılaşabileceği düşünülmektedir. Çalışanların bankacılık faaliyetlerini yerine getirirken ve müşterilerle iletişim kurarken iş çevresinden sosyal desteğe ihtiyaç duyabileceği tahmin edilmektedir. Banka çalışanlarının genel olarak müşterilerle kurduğu iletişim esnasında belirli davranış kurallarına uyması beklenmektedir. Gişe/operasyon çalışanları bu kuralların dışına çıkmayacak şekilde müşterilere karşı doğal bir şekilde yaklaşabilmekte ve müşterilerin isteklerini yerine getirebilmektedir. Bu hususlar gözetildiğinde araştırmanın gişe/ operasyon çalışanları kapsamında yapılmasının uygun olduğu düşünülmektedir.

\subsection{Araştırmada Kullanılan Ölçekler}

Araştırmada üç ölçekten yararlanılmıştır. İşe yabancılaşma ölçeği Mottaz (1981) tarafından geliştirilmiştir. Ölçek toplam 3 boyuttan ve 21 ifadeden oluşmaktadır. Algılanan sosyal destek ölçeği Payne, Andrew, Butler, Wyatt, Dubbert \& Mosley (2012) tarafından geliştirilmiştir. Ölçek toplam 4 boyuttan ve 16 ifadeden oluşmaktadır. Doğal davranış ölçeğine ilişkin sorular ise Diefendorff, Croyle \& Gosserand (2005) tarafından geliştirilen duygusal emek ölçeğinde yer almaktadır. Duygusal emek ölçeğinin boyutlarından birini oluşturan doğal davranış toplam 3 ifade ile ölçülmektedir.

\subsection{Araştırmanın Modeli}

Araştırmanın amacı doğrultusunda oluşturulan model Şekil l'de yer almaktadır.

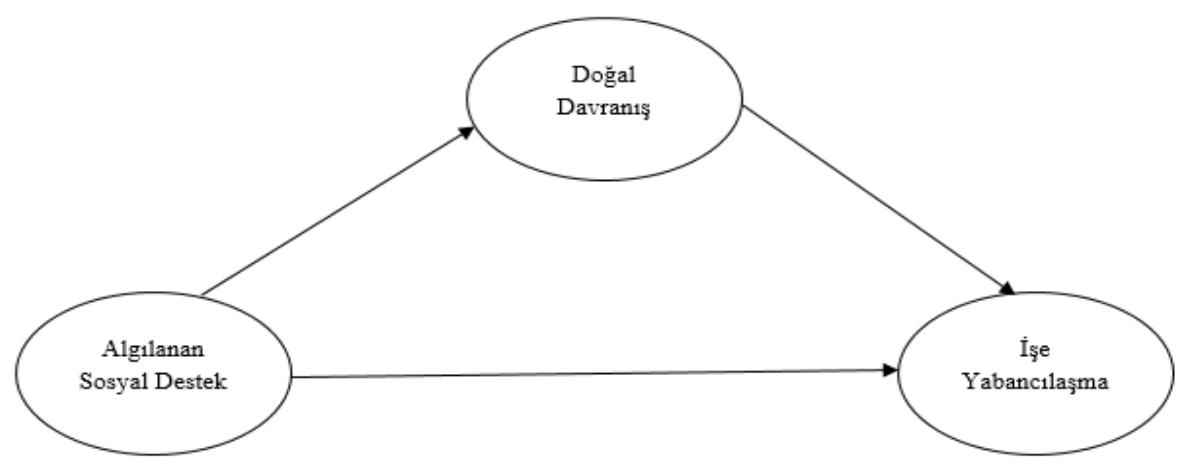

Şekil 1: Araştırmanın Modeli 


\section{4. İşe Yabancılaşmaya İlişkin Geçerlilik ve Güvenilirlik Analizi}

\subsection{1 İşe Yabancılaşmaya İliş̧kin Doğrulayıcı Faktör Analizi}

Teorik modelde yer alan faktör yapıları AMOS programı kullanılarak doğrulayıcı faktör analizi ile doğrulanmıştır. Geçerlilik analizinden sonra her ölçekte yer alan faktörlerin güvenilirlik katsayıları hesaplanmıştır. Bu doğrultuda ilk önce işe yabancılaşma ölçeğine ilişkin geçerlilik ve güvenilirlik analizi gerçekleştirilmiştir. Toplam 3 boyut ve 21 ifadeden oluşan işe yabancılaşmaya ilişkin doğrulayıcı faktör analizi yapabilmek için birinci düzey çok faktörlü model kullanılmıştır. İşe yabancılaşmaya ilişkin doğrulayıcı faktör analizinin sonuçları Şekil 2'de yer almaktadır.

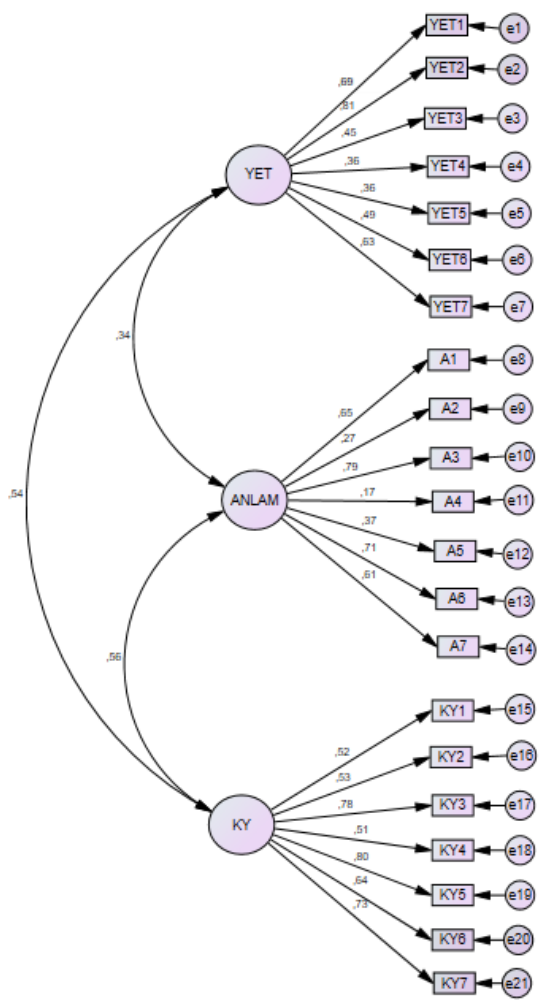

Şekil 2: İşe Yabancılaşmaya İliş̧kin Doğrulayıcı Faktör Analizi (Model 1) "YET: Yetkisizlik", "ANLAM: Anlamsızlık", "KY: Kendine Yabancılaşma"

Faktör yapılarının doğrulanabilmesi için model yapısının verilerle uyumlu olması gerekmektedir. Bu uyumun ortaya konulabilmesi için uyum indekslerinden faydalanılmaktadır. Dolayısıyla doğrulayıcı faktör analizi sonucunda oluşan uyum değerlerinin uyum indeksinde belirlenen kriterlere uygun olması gerekmektedir (Kartal \& Bardakçı, 2018). Genel olarak uyum değerlerinin şu şekilde olması gerekmektedir (Schermelleh-Engel, Moosbrugger \& Müller, 2003; Meydan \& Şeşen, 2015; Abrahim, Mir, Suhara, Mohamed \& Sato, 2019; Karagöz, 2016). 
Tablo 1: Doğrulayıcı Faktör Analizi Uyum Değerleri

\begin{tabular}{lcc}
\hline & İyi Uyum & Kabul Edilebilir Uyum \\
\hline CMIN/DF & $\leq 3$ & $\leq 4-5$ \\
CFI & $\geq 0,97$ & $\geq 0,95$ \\
GFI & $\geq 0,90$ & $089-0,85$ \\
AGFI & $\geq 0,90$ & $089-0,85$ \\
RMSEA & $\leq 0,05$ & $0,06-0,08$ \\
NFI & $\geq 0,95$ & $0,94-0,90$ \\
IFI & $\geq 0,95$ & $0,94-0,90$ \\
\hline
\end{tabular}

\section{Model 1}

İlk aşamada gerçekleştirilen doğrulayıcı faktör analizine ilişkin uyum değerleri incelendiğinde CFI, GFI, AGFI, RMSEA, NFI ve IFI uyum değerlerinin istenen seviyede olmadığı görülmektedir. İşe yabancılaşmaya ilişkin uyum değerleri Tablo 2'de yer almaktadır.

Tablo 2: İșe Yabancılaşmaya İlişkin Uyum Değerleri (Model 1)

\begin{tabular}{lccc}
\hline & İyi Uyum & Kabul Edilebilir Uyum & Uyum Değerleri \\
\hline CMIN/DF & $\leq 3$ & $\leq 4-5$ & 4,508 \\
CFI & $\geq 0,97$ & $\geq 0,95$ & $\mathbf{0 , 7 5 1}$ \\
GFI & $\geq 0,90$ & $089-0,85$ & $\mathbf{0 , 7 7 9}$ \\
AGFI & $\geq 0,90$ & $089-0,85$ & $\mathbf{0 , 7 2 5}$ \\
RMSEA & $\leq 0,05$ & $0,06-0,08$ & $\mathbf{0 , 0 9 7}$ \\
NFI & $\geq 0,95$ & $0,94-0,90$ & $\mathbf{0 , 7 0 4}$ \\
IFI & $\geq 0,95$ & $0,94-0,90$ & $\mathbf{0 , 7 5 4}$ \\
\hline
\end{tabular}

\section{Model 2}

Uyum değerlerini iyileştirebilmek için ilk önce standart regresyon katsayıları incelenmiştir. A2 ve A4 ifadelerinin standart regresyon katsayıları düşük olduğu için modelden çıkarılmasına karar verilmiştir. A2 ve A4 ifadelerinin modelden çıkarılması sonucunda oluşan uyum değerleri Tablo 3'de yer almaktadir.

Tablo 3: İşe Yabancılaşmaya İlişkin Uyum Değerleri (Model 2)

\begin{tabular}{lccc}
\hline & İyi Uyum & Kabul Edilebilir Uyum & Uyum Değerleri \\
\hline CMIN/DF & $\leq 3$ & $\leq 4-5$ & 4,610 \\
CFI & $\geq 0,97$ & $\geq 0,95$ & $\mathbf{0 , 7 8 3}$ \\
GFI & $\geq 0,90$ & $089-0,85$ & $\mathbf{0 , 8 0 2}$ \\
AGFI & $\geq 0,90$ & $089-0,85$ & $\mathbf{0 , 7 4 8}$ \\
RMSEA & $\leq 0,05$ & $0,06-0,08$ & $\mathbf{0 , 0 9 8}$ \\
NFI & $\geq 0,95$ & $0,94-0,90$ & $\mathbf{0 , 7 4 1}$ \\
IFI & $\geq 0,95$ & $0,94-0,90$ & $\mathbf{0 , 7 8 5}$ \\
\hline
\end{tabular}


İşe yabancılaşmaya ilişkin doğrulayıcı faktör analizinin sonuçları Şekil 3'de yer almaktadır.

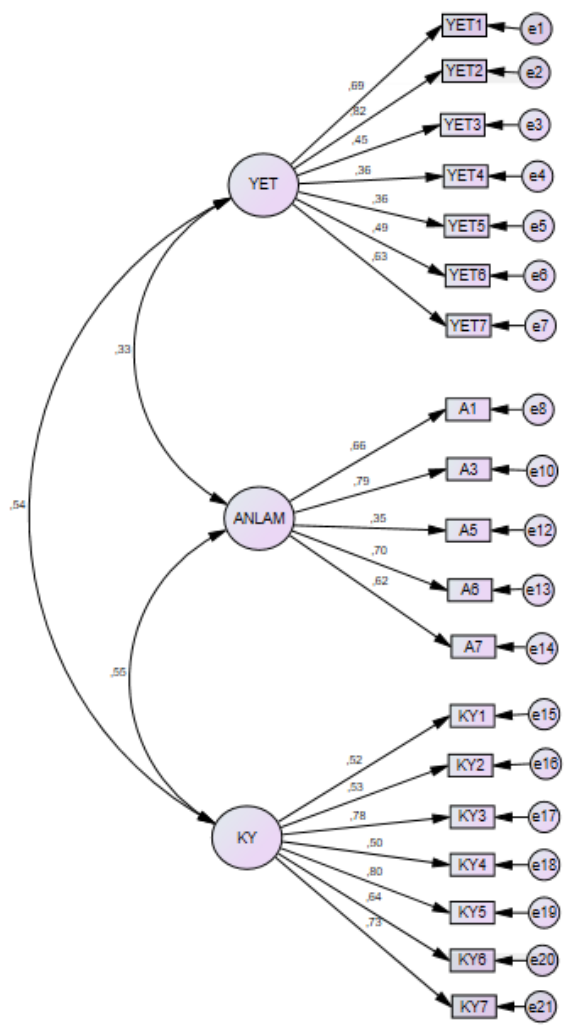

Şekil 3: İşe Yabancılaşmaya İlişkin Doğrulayıcı Faktör Analizi (Model 2)

"YET: Yetkisizlik", "ANLAM: Anlamsızlık", KY: Kendine Yabancılaşma"

\section{Model 3}

Model 2 sonucunda CFI, GFI, AGFI, RMSEA, NFI ve IFI değerlerinin istenen uyum seviyesine ulaşmadığ1 görülmektedir. Bu doğrultuda standart regresyon yükleri tekrar incelenmiştir. YET4, YET5 ve A5 ifadelerinin standart regresyon yükleri düşük olduğu için modelden çıkarılmasına karar verilmiştir. YET4, YET5 ve A5 ifadelerinin modelden çıkarılması sonucunda oluşan uyum değerleri Tablo 4'de yer almaktadir.

Tablo 4: İşe Yabancılaşmaya İlişkin Uyum Değerleri (Model 3)

\begin{tabular}{lccc}
\hline & İyi Uyum & Kabul Edilebilir Uyum & Uyum Değerleri \\
\hline CMIN/DF & $\leq 3$ & $\leq 4-5$ & 4,951 \\
CFI & $\geq 0,97$ & $\geq 0,95$ & $\mathbf{0 , 8 2 1}$ \\
GFI & $\geq 0,90$ & $089-0,85$ & $\mathbf{0 , 8 3 8}$ \\
AGFI & $\geq 0,90$ & $089-0,85$ & $\mathbf{0 , 7 8 1}$ \\
RMSEA & $\leq 0,05$ & $0,06-0,08$ & $\mathbf{0 , 1 0 3}$
\end{tabular}




\begin{tabular}{llll} 
NFI & $\geq 0,95$ & $0,94-0,90$ & $\mathbf{0 , 7 8 7}$ \\
IFI & $\geq 0,95$ & $0,94-0,90$ & $\mathbf{0 , 8 2 2}$ \\
\hline
\end{tabular}

İşe yabancılaşmaya ilişkin doğrulayıcı faktör analizinin sonuçları Şekil 4'de yer almaktadır.

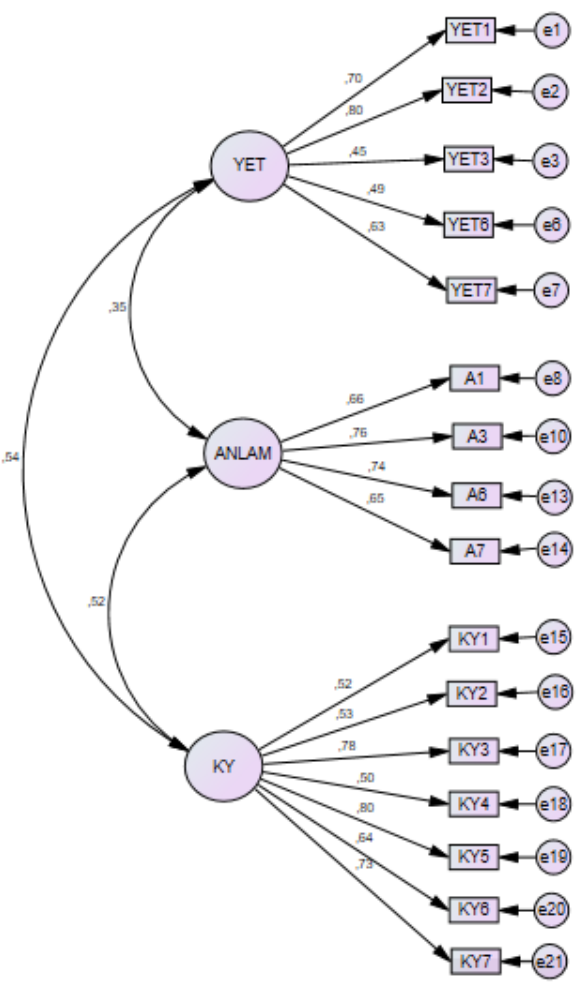

Şekil 4: İşe Yabancılaşmaya İlişkin Doğrulayıcı Faktör Analizi (Model 3)

"YET: Yetkisizlik", "ANLAM: Anlamsızlık", "KY: Kendine Yabancılaşma"

\section{Model 4}

Model 3 sonunda CFI, GFI, AGFI, RMSEA, NFI ve IFI değerlerinin istenen seviyeye gelmediği görülmektedir. İfadelerin regresyon yükleri incelendiğinde YET3 ifadesinin standart regresyon yükü düşük olduğu için modelden çıkarılmasına karar verilmiştir. Bununla birlikte modifikasyon indisleri incelendiğinde yüksek ölçüm hatasına sahip ifadelerin olduğu tespit edilmiştir. Yüksek ölçüm hatasına sahip ifadeler Tablo 5'de yer almaktadır.

Tablo 5: Yüksek Hata Değerlerine Sahip İfadeler (İşe Yabancılaşma)

\begin{tabular}{cc}
\hline Hata Değerleri & Modifikasyon İndisleri (MI) \\
\hline e13 $<->$ e14 & 42,476
\end{tabular}



$\mathrm{e} 15<->\mathrm{e} 16$
31,282
$\mathrm{e} 18<->\mathrm{e} 20$
26,096

Yüksek ölçüm hatasına sahip e13-e14, e15-e16 ve e18-e20 hata terimlerinin birbiriyle ilişkilendirilmesi ve YET3 ifadesinin modelden çıkarılması sonucunda oluşan uyum değerleri Tablo 6'da yer almaktadır.

Tablo 6: İşe Yabancılaşmaya İlişskin Uyum Değerleri (Model 4)

\begin{tabular}{lccc}
\hline & İyi Uyum & Kabul Edilebilir Uyum & Uyum Değerleri \\
\hline CMIN/DF & $\leq 3$ & $\leq 4-5$ & 3,341 \\
CFI & $\geq 0,97$ & $\geq 0,95$ & $\mathbf{0 , 9 0 6}$ \\
GFI & $\geq 0,90$ & $089-0,85$ & 0,904 \\
AGFI & $\geq 0,90$ & $089-0,85$ & 0,862 \\
RMSEA & $\leq 0,05$ & $0,06-0,08$ & 0,079 \\
NFI & $\geq 0,95$ & $0,94-0,90$ & $\mathbf{0 , 8 7 2}$ \\
IFI & $\geq 0,95$ & $0,94-0,90$ & 0,907 \\
\hline
\end{tabular}

İşe yabancılaşmaya ilişskin doğrulayıcı faktör analizinin sonuçları Şekil 5’de yer almaktadır.

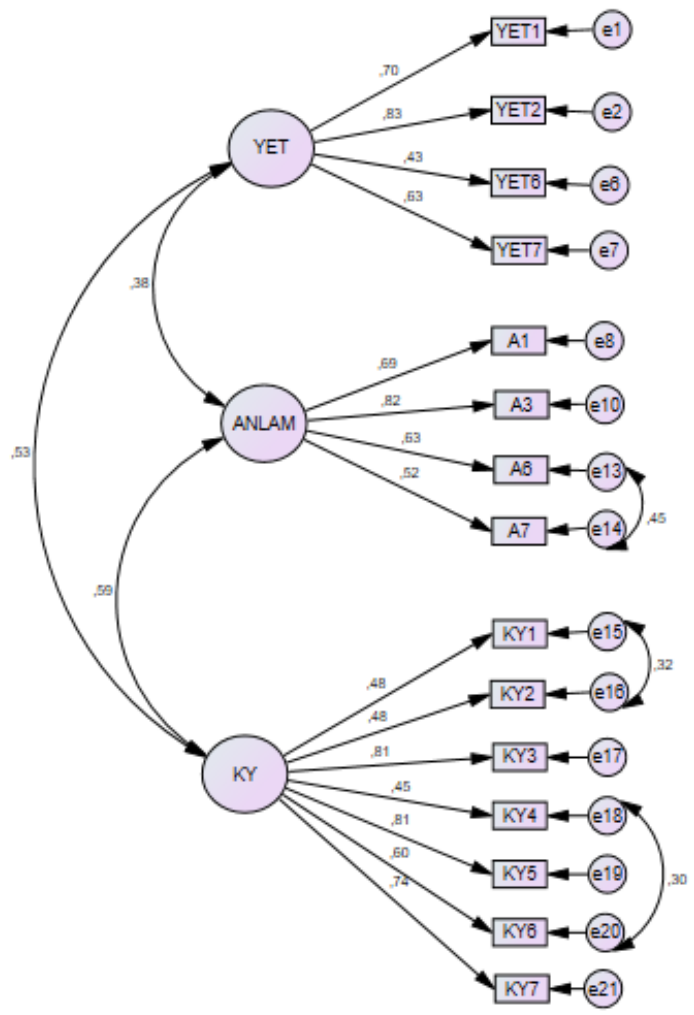

Şekil 5: İşe Yabancılaşmaya İlişsin Doğrulayıcı Faktör Analizi (Model 4) "YET: Yetkisizlik", "ANLAM: Anlamsızlık”, "KY: Kendine Yabancılaşma” 
Model 4 sonunda oluşan uyum değerleri sonucunda GFI değerinin iyi uyum gösterdiği, CMIN/DF, AGFI, RMSEA ve IFI uyum değerlerinin ise kabul edilebilir uyum gösterdiği görülmektedir. CFI ve NFI değerlerinin ise istenen düzeyin altında kalmakla birlikte, kabul edilebilir sınır eşiğine yakın olduğu söylenebilmektedir. Modelde yer alan ifadelere ilişkin standardize regresyon yükleri Tablo 7'de yer almaktadir.

Tablo 7: İșe Yabancılaşmaya İliş̧kin Standardize Regresyon Yükleri

\begin{tabular}{clc}
$\begin{array}{c}\text { İfade } \\
\text { Kısaltması }\end{array}$ & İfade & $\begin{array}{c}\text { Standardize } \\
\text { R e g r e s y on } \\
\text { Yüikleri }\end{array}$ \\
\hline YET1 & Günlük işlerimi yerine getirirken önemli ölçüde serbest davranma imkânına sahibim & 0,700 \\
YET2 & İşle ilgili kendi kararlarımı uygulama şansına sahibim & 0,835 \\
YET6 & Günlük işlerimin çoğu başkaları tarafından belirlenir & 0,431 \\
YET7 & İşimi yaparken kararlarımı kendim veririm & 0,633 \\
A1 & Yaptığım iş çalıştı̆̆ım kurumun başarısına önemli katkı sağlıyor & 0,695 \\
A3 & Yaptığım iş gerçekten önemli ve değerlidir & 0,820 \\
A6 & Yaptığım işin kurumdaki bütün faaliyetlerle olan ilgisini anlayabiliyorum & 0,629 \\
A7 & Yaptığım işin diğer çalışanların yaptı̆̆ı işlerle ilgisinin ne olduğunu bilirim & 0,524 \\
KY1 & Yaptığım iş bana başarma hissi vermiyor & 0,479 \\
KY2 & İş hayatımda paradan başka elde ettiğim bir şey yok & 0,483 \\
KY3 & Yaptığım iș bana kişisel tatmin hissi veriyor & 0,809 \\
KY4 & Yaptığım işlerde gerçek yeteneklerimi sergileme imkânım çok fazla yok & 0,455 \\
KY5 & İşim bana kendimi gerçekleştirme imkânı verir & 0,814 \\
KY6 & Yaptığım iş benim için yaratııılık istemeyen sıkıcı ve monoton bir iştir & 0,598 \\
KY7 & Yaptığım iş her yönüyle benim için ilgi çekici ve merak uyandırıcıdır & 0,736 \\
\hline
\end{tabular}

\subsection{2 İşe Yabancılaşmaya İlişkin Güvenilirlik Analizi}

Ölçeklere ilişkin güvenilirlik analizi yapılırken ifadelerin iç tutarlılığını gösteren Cronbach Alpha katsayısından yararlanılmaktadır. Cronbach Alpha katsayısı ölçekte yer alan ifadelerin homojen yapısını açıklamak üzere kullanılmaktadır. Cronbach Alpha katsayısının yüksek olması ifadelerin birbiriyle tutarlı olduğunu göstermektedir. Cronbach Alpha katsayısına ilişkin değer aralıkları aşağıda yer almaktadır (Yıldız \& Uzunsakal, 2018):

$$
\begin{aligned}
& 0<\mathrm{R}^{2}<0,40 \text { ise güvenilir değil } \\
& 0.40<\mathrm{R}^{2}<0.60 \text { ise düşük güvenilirlik } \\
& 0.60<\mathrm{R}^{2}<0.80 \text { ise oldukça güvenilir } \\
& 0.80<\mathrm{R}^{2}<1.00 \text { ise yüksek güvenilirlik }
\end{aligned}
$$

İşe yabancılaşmaya ilişkin iç tutarlılığı tespit etmek için Cronbach Alpha değerinden yararlanılmıştır. $\mathrm{Bu}$ doğrultuda işe yabancılaşma ölçeğinin Cronbach Alpha değeri hesaplanmıştır. İşe 
yabancılaşmanın Cronbach Alpha değeri 0,853 olarak tespit edilmiştir. Buna göre işe yabancılaşma ölçeğinin yüksek güvenilirliğe sahip olduğu söylenebilmektedir. İşe yabancılaşmanın boyutlarından yetkisizliğin Cronbach Alpha değeri 0,737, anlamsızlı̆̆ın Cronbach Alpha değeri 0,792 ve kendine yabancılaşmanın Cronbach Alpha değeri de 0,840 olarak hesaplanmıştır. Bu durumda yetkisizlik ile anlamsızlık boyutlarına ilişkin iç tutarlılığın oldukça güvenilir ve kendine yabancılaşma boyutuna ilişkin iç tutarlılığın ise yüksek güvenilirliğe sahip olduğu söylenebilmektedir.

\subsection{Algılanan Sosyal Desteğe İlişkin Geçerlilik ve Güvenilirlik Analizi}

\subsubsection{Algılanan Sosyal Desteğe İlişkin Doğrulayıcı Faktör Analizi}

Algılanan sosyal destek ölçeği toplam 16 ifade ve 4 boyuttan oluşmaktadır. Doğrulayıcı faktör analizi ile bu yapının onaylanması gerekmektedir. Algılanan sosyal desteğe ilişkin doğrulayıcı faktör analizini yapabilmek için birinci düzey çok faktörlü modelden yararlanılmıştır. Gözlenebilen 16 ifade birbirinden bağımsız 4 faktör altında toplanmaktadır. Bu doğrultuda algılanan sosyal desteğe ilişkin doğrulayıcı faktör analizi gerçekleştirilmiştir. Algılanan sosyal desteğe ilişkin doğrulayıcı faktör analizinin sonuçları Şekil 6’de yer almaktadır.

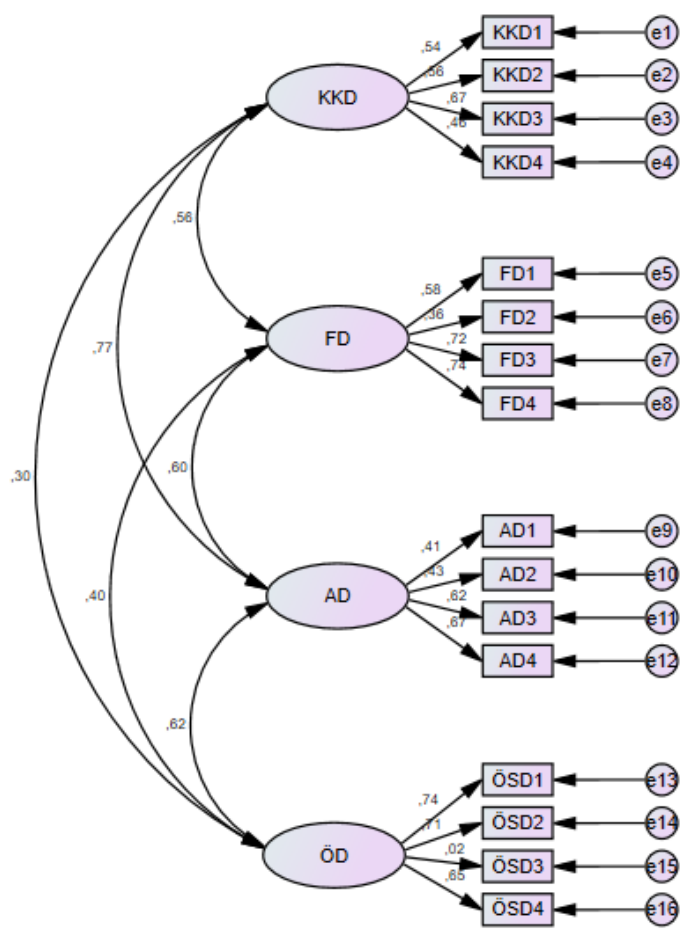

Şekil 6: Algılanan Sosyal Desteğe İlişkin Doğrulayıcı Faktör Analizi (Model 1)

"KKD: Kişisel Konularda Destek”, "FD: Fiziksel Destek”, “AD: Aidiyet Desteği”, “ÖD: Özsaygı Desteği” 


\section{Model 1}

İlk modelde doğrulayıcı faktör analizi sonucunda ortaya çıkan faktör yapılarının doğrulanması amaçlanmaktadır. İlk modelde gerçekleştirilen doğrulayıcı faktör analizi kapsamında algılanan sosyal desteğe ilişkin uyum değerleri incelendiğinde CMIN/DF, CFI, GFI, AGFI, NFI, IFI ve RMSEA uyum değerlerinin istenen seviyede olmadığı görülmektedir. Algılanan sosyal desteğe ilişkin uyum değerleri Tablo 8'de yer almaktadır.

Tablo 8: Algılanan Sosyal Desteğe İlişkin Uyum Değerleri (Model 1)

\begin{tabular}{lccc}
\hline & İyi Uyum & Kabul Edilebilir Uyum & Uyum Değerleri \\
\hline CMIN/DF & $\leq 3$ & $\leq 4-5$ & $\mathbf{7 , 3 3 0}$ \\
CFI & $\geq 0,97$ & $\geq 0,95$ & $\mathbf{0 , 6 4 3}$ \\
GFI & $\geq 0,90$ & $089-0,85$ & $\mathbf{0 , 7 5 7}$ \\
AGFI & $\geq 0,90$ & $089-0,85$ & $\mathbf{0 , 6 6 3}$ \\
RMSEA & $\leq 0,05$ & $0,06-0,08$ & $\mathbf{0 , 1 3 0}$ \\
NFI & $\geq 0,95$ & $0,94-0,90$ & $\mathbf{0 , 6 1 4}$ \\
IFI & $\geq 0,95$ & $0,94-0,90$ & $\mathbf{0 , 6 4 8}$ \\
\hline
\end{tabular}

\section{Model 2}

Algılanan sosyal desteğe ilişkin ilk modelde uyum değerleri istenen seviyede bulunmamaktadır. Uyum değerlerini iyileştirebilmek için ilk önce standart regresyon yükleri incelenmiştir. Standart regresyon yükleri düşük olan OSD3 ifadesi modelden çıkarılmıştır. OSD3 ifadesinin modelden çıkarılması sonucunda oluşan uyum değerleri Tablo 9'da yer almaktadır.

Tablo 9: Algılanan Sosyal Desteğe Uyum Değerleri (Model 2)

\begin{tabular}{lccc}
\hline & İyi Uyum & Kabul Edilebilir Uyum & Uyum Değerleri \\
\hline CMIN/DF & $\leq 3$ & $\leq 4-5$ & $\mathbf{7 , 9 4 3}$ \\
CFI & $\geq 0,97$ & $\geq 0,95$ & $\mathbf{0 , 6 5 8}$ \\
GFI & $\geq 0,90$ & $089-0,85$ & $\mathbf{0 , 7 6 6}$ \\
AGFI & $\geq 0,90$ & $089-0,85$ & $\mathbf{0 , 6 6 6}$ \\
RMSEA & $\leq 0,05$ & $0,06-0,08$ & $\mathbf{0 , 1 3 6}$ \\
NFI & $\geq 0,95$ & $0,94-0,90$ & $\mathbf{0 , 6 3 1}$ \\
IFI & $\geq 0,95$ & $0,94-0,90$ & $\mathbf{0 , 6 6 2}$ \\
\hline
\end{tabular}

Algılanan sosyal desteğe ilişkin doğrulayıcı faktör analizinin sonuçları Şekil 7’de yer almaktadır. 


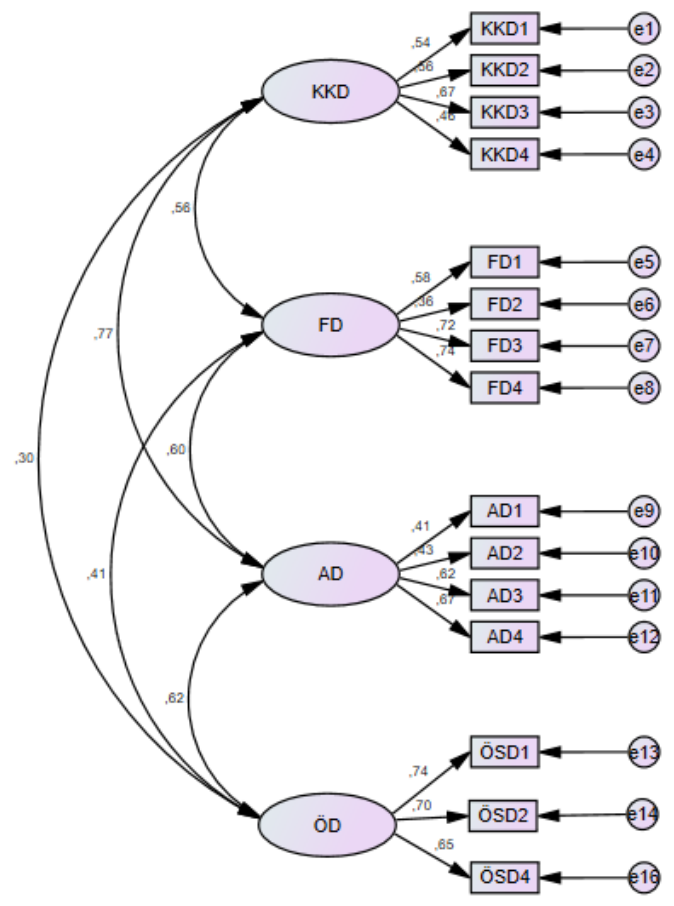

Şekil 7: Algılanan Sosyal Desteğe İlişkin Doğrulayıcı Faktör Analizi (Model 2)

"KKD: Kişisel Konularda Destek”, "FD: Fiziksel Destek”, “AD: Aidiyet Desteği”, "ÖD: Özsaygı Desteği”

\section{Model 3}

Model 2 sonucunda CMIN/DF, CFI, GFI, AGFI, RMSEA, NFI ve IFI uyum değerlerinin istenen seviyeye ulaşmadığı tespit edilmiştir. Yapılan inceleme neticesinde AD1, AD2 ve KKD4 ifadelerinin birden fazla ifadeyle yüksek regresyon yükü paylaştığ1, FD2 ifadesinin ise regresyon yükünün düşük olduğu ortaya çıkmıştır. Dolayısıyla AD1, AD2, KKD4 ve FD2 ifadeleri modelden çıkarılmıştır. AD1, $\mathrm{AD} 2, \mathrm{KKD} 4$ ve FD2 ifadelerinin modelden çıkarılması sonucunda oluşan uyum değerleri Tablo 10 'da yer almaktadir.

Tablo 10: Algılanan Sosyal Desteğe İlişkin Uyum Değerleri (Model 3)

\begin{tabular}{lccc}
\hline & İyi Uyum & Kabul Edilebilir Uyum & Uyum Değerleri \\
\hline CMIN/DF & $\leq 3$ & $\leq 4-5$ & 3,573 \\
CFI & $\geq 0,97$ & $\geq 0,95$ & $\mathbf{0 , 9 1 0}$ \\
GFI & $\geq 0,90$ & $089-0,85$ & 0,939 \\
AGFI & $\geq 0,90$ & $089-0,85$ & 0,894 \\
RMSEA & $\leq 0,05$ & $0,06-0,08$ & $\mathbf{0 , 0 8 3}$ \\
NFI & $\geq 0,95$ & $0,94-0,90$ & $\mathbf{0 , 8 8 1}$ \\
IFI & $\geq 0,95$ & $0,94-0,90$ & 0,911 \\
\hline
\end{tabular}


Algılanan sosyal desteğe ilişkin doğrulayıcı faktör analizinin sonuçları Şekil 8'de yer almaktadır.

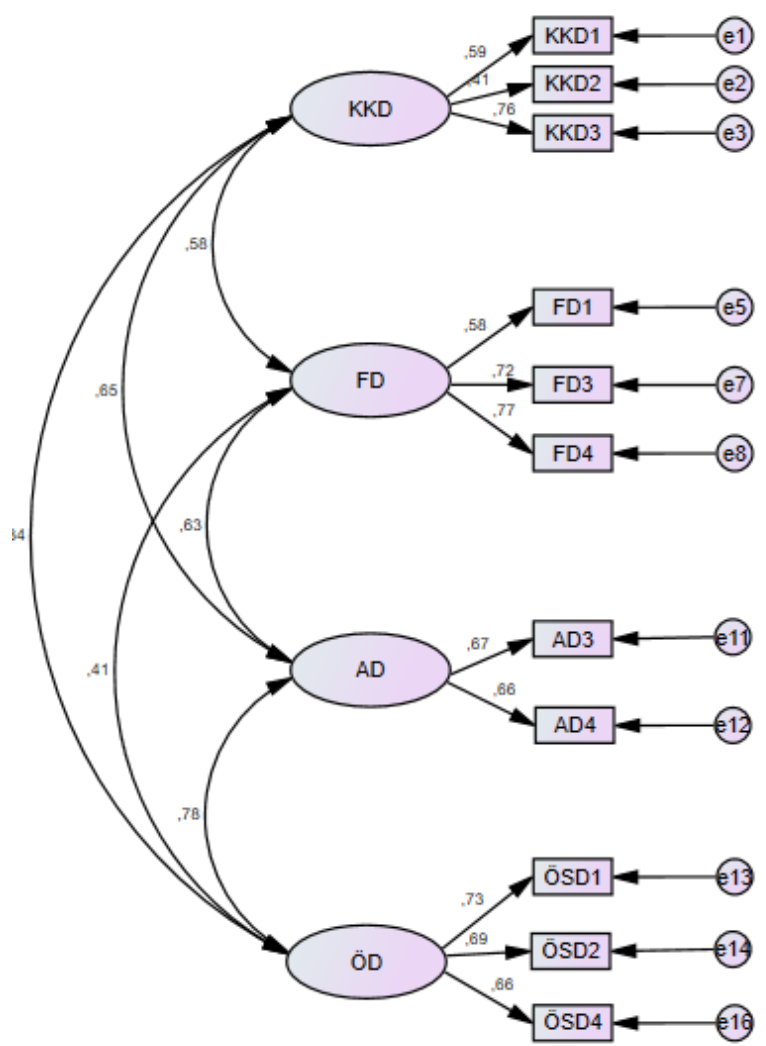

Şekil 8: Algılanan Sosyal Desteğe İlişkin Doğrulayıcı Faktör Analizi (Model 3)

"KKD: Kişisel Konularda Destek”, "FD: Fiziksel Destek”, “AD: Aidiyet Desteği”, “ÖD: Özsaygı Desteği”

\section{Model 4}

Model 3 sonucunda CFI, RMSEA ve NFI uyum değerlerinin istenen seviyeye ulaşmadığı tespit edilmiştir. Modifikasyon indisleri incelendiğinde yüksek ölçüm hatasına sahip ifadelerin olduğu tespit edilmiştir. Yüksek ölçüm hatasına sahip ifadeler Tablo 11'de yer almaktadır.

Tablo 11: Yüksek Hata Değerlerine Sahip İfadeler (Algılanan Sosyal Destek)

\begin{tabular}{cc}
\hline Hata Değerleri & Modifikasyon İndisleri (MI) \\
\hline e13 $<->$ e14 & 16,686 \\
\hline
\end{tabular}

Yüksek ölçüm hatasına sahip e13-e14 hata terimlerinin birbiriyle ilişkilendirilmesi sonucunda oluşan uyum değerleri Tablo 12'de yer almaktadır. 
Tablo 12: Algılanan Sosyal Desteğe İlişkin Uyum Değerleri (Model 4)

\begin{tabular}{llll}
\hline & İyi Uyum & Kabul Edilebilir Uyum & Uyum Değerleri \\
\hline CMIN/DF & $\leq 3$ & $\leq 4-5$ & 2,350 \\
CFI & $\geq 0,97$ & $\geq 0,95$ & 0,954 \\
GFI & $\geq 0,90$ & $089-0,85$ & 0,958 \\
AGFI & $\geq 0,90$ & $089-0,85$ & 0,926 \\
RMSEA & $\leq 0,05$ & $0,06-0,08$ & 0,060 \\
NFI & $\geq 0,95$ & $0,94-0,90$ & 0,924 \\
IFI & $\geq 0,95$ & $0,94-0,90$ & 0,955 \\
\hline
\end{tabular}

Algılanan sosyal desteğe ilişkin doğrulayıcı faktör analizinin sonuçları Şekil 9'da yer almaktadır.

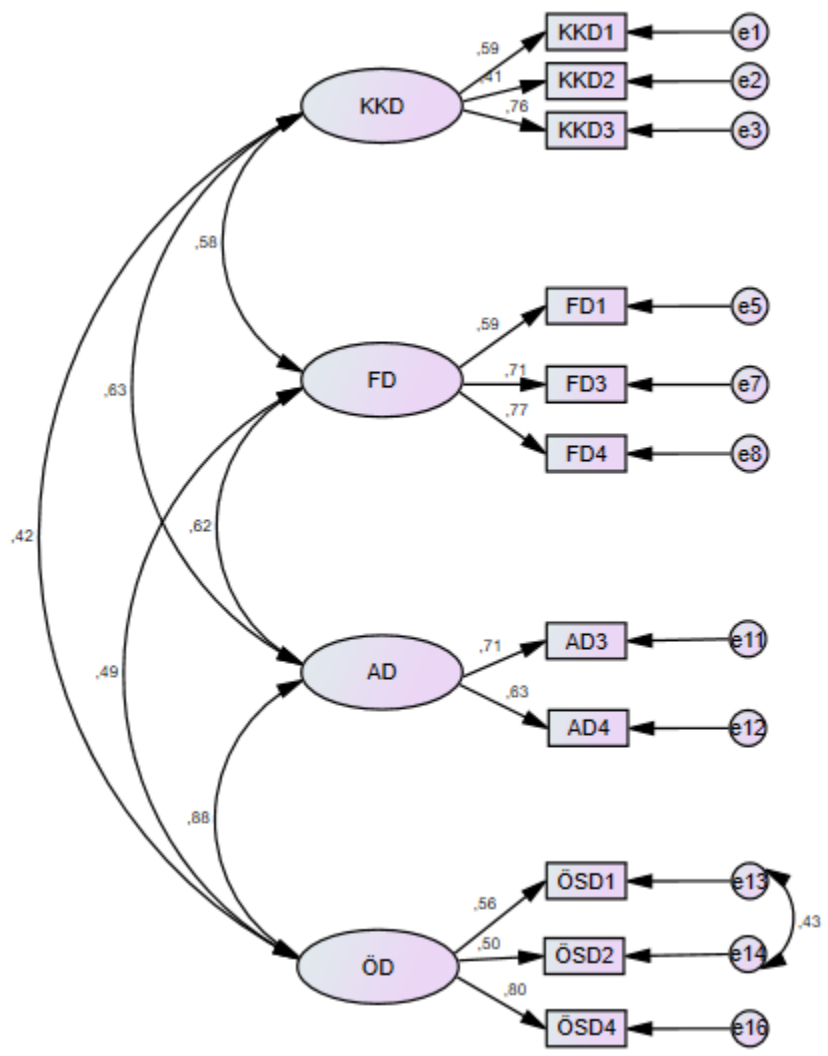

Şekil 9: Algılanan Sosyal Desteğe İlişkin Doğrulayıcı Faktör Analizi (Model 4)

"KKD: Kişisel Konularda Destek”, "FD: Fiziksel Destek”, “AD: Aidiyet Desteği”, "ÖD: Özsaygı Desteği”

Model 4 sonucunda CMIN/DF, GFI, AGFI ve IFI değerlerinin iyi uyum gösterdiği, CFI, RMSEA ve NFI değerlerinin de kabul edilebilir uyum gösterdiği görülmektedir. Bu doğrultuda algılanan sosyal destek ölçeğine ilişkin ifadelerin standardize regresyon yükleri Tablo 13'de yer almaktadır. 
Tablo 13: Algılanan Sosyal Desteğe İlişkin Standardize Regresyon Yükleri

\begin{tabular}{|c|c|c|}
\hline $\begin{array}{c}\text { Iffade } \\
\text { Kisaltmasi }\end{array}$ & İfade & $\begin{array}{c}\text { Standardize } \\
\text { Regresyon } \\
\text { Yükleri }\end{array}$ \\
\hline KKD1 & $\begin{array}{l}\text { Kişisel sorunlarımın nasıl üstesinden geleceğime dair iş çevremde bana tarafsız görüş } \\
\text { verebilecek biri yok }\end{array}$ & 0,588 \\
\hline KKD2 & $\begin{array}{l}\text { Kişisel bir sorunla nasıl başa çıkabileceğim hususunda tavsiyelere ihtiyacım olduğunda, iş } \\
\text { çevremde yardım isteyebileceğim birisi mutlaka vardır }\end{array}$ & 0,413 \\
\hline KKD3 & İş çevremde finansal açıdan faydalı tavsiyelerde bulunabilecek güvendiğim hiç kimse yok & 0,761 \\
\hline FD1 & $\begin{array}{l}\text { Hasta olsam ve beni doktora götürecek birine ihtiyaç duysam, iş çevremden birini bulmakta } \\
\text { sorun yaşarım }\end{array}$ & 0,585 \\
\hline FD3 & $\begin{array}{l}\text { Birkaç hafta şehir dişına çıkmak zorunda kalsam, evime (bitki, evcil hayvan, bahçe vb.) } \\
\text { bakacak birini iş çevremden bulmakta çok zorluk çekerim }\end{array}$ & 0,714 \\
\hline FD4 & Birkaç saatliğine bana aracını ödünç verecek birini iş çevremden bulmakta çok zorluk çekerim & 0,769 \\
\hline AD3 & İşyerindeki arkadaş çevreme sürekli olarak dâhil edilmediğimi hissederim & 0,707 \\
\hline $\mathrm{AD} 4$ & Birlikte bir şeyler yapmak üzere iş arkadaşlarımdan çok sık davet almam & 0,632 \\
\hline OSD1 & İş arkadaşlarımın çoğu benden daha ilgi çekicidir & 0,557 \\
\hline OSD2 & İş arkadaşlarımın çoğu hayatlarında değişiklik yapmak konusunda benden daha başarılıdır & 0,505 \\
\hline OSD4 & İş arkadaşlarıma ayak uydurmakta zorluk çekerim & 0,801 \\
\hline
\end{tabular}

\subsubsection{Algılanan Sosyal Desteğe İlişkin Güvenilirlik Analizi}

Algılanan sosyal desteğe ilişkin iç tutarlılığı tespit etmek için Cronbach Alpha değerinden yararlanılmıştır. Bu doğrultuda algılanan sosyal destek ölçeğinin Cronbach Alpha değeri hesaplanmıştır. Algılanan sosyal desteğin Cronbach Alpha değeri 0,805 olarak tespit edilmiştir. Buna göre algılanan sosyal destek ölçeğinin yüksek güvenilirliğe sahip olduğu söylenebilmektedir. Algılanan sosyal desteğin boyutlarından kişisel konularda desteğin Cronbach Alpha değeri 0,606, fiziksel desteğin Cronbach Alpha değeri 0,723, aidiyet desteğinin Cronbach Alpha değeri 0,617 ve özsaygı desteğinin Cronbach Alpha değeri de 0,733 olarak hesaplanmıştır. Bu sonuçlara göre algılanan sosyal destek boyutlarına yönelik iç tutarlılığın oldukça güvenilir olduğu ifade edilebilmektedir.

\subsection{Doğal Davranışa İlişkin Geçerlilik ve Güvenilirlik Analizi}

\subsubsection{Doğal Davranışa İlişkin Doğrulayıcı Faktör Analizi}

Doğal davranış ölçeği toplam 3 ifadeden ve tek boyuttan oluşmaktadır. Doğrulayıcı faktör analizi ile bu yapının onaylanması gerekmektedir. Dolayısıyla bu aşamada AMOS paket programı bu yapının testi gerçekleştirilmiştir. Doğal davranışa ilişkin doğrulayıcı faktör analizini yapabilmek için tek faktörlü modelden yararlanılması gerekmektedir. Nitekim tek faktörlü model kapsamında gözlenebilen 3 ifade tek faktör olan doğal davranış altında toplanmaktadır. Bu doğrultuda doğal davranışa ilişkin doğrulayıcı faktör analizi gerçekleştirilmiştir. Doğal davranışa ilişkin doğrulayıcı faktör analizinin sonuçları Şekil 10’da yer almaktadır. 


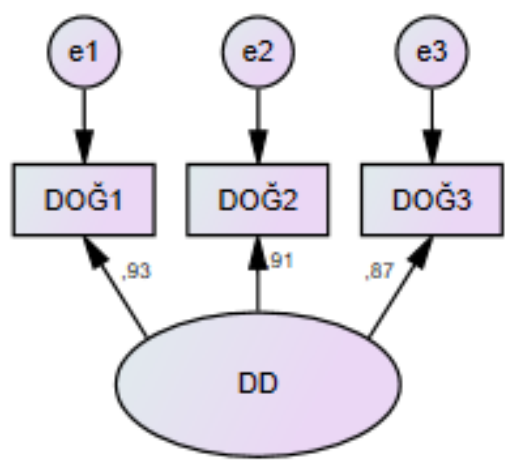

Şekil 10: Doğal Davranışa İlişkin Doğrulayıcı Faktör Analizi (Model 1)

“DD: Doğal Davranış"

\section{Model 1}

İlk modelde gerçekleştirilen doğrulayıcı faktör analizi kapsamında doğal davranışa ilişkin uyum değerleri incelendiğinde bütün uyum değerlerinin iyi bir uyum gösterdiği ifade edilebilmektedir. RMSEA uyum değeri kabul edilebilir uyum değerinden düşük olmakla birlikte eşik değer olan 0,08’e yakındır. Doğal davranışa ilişkin uyum değerleri Tablo 14'de yer almaktadır.

Tablo 14: Doğal Davranışa İlişkin Uyum Değerleri (Model 1)

\begin{tabular}{lccc}
\hline & İyi Uyum & Kabul Edilebilir Uyum & Uyum Değerleri \\
\hline CMIN/DF & $\leq 3$ & $\leq 4-5$ & 3,696 \\
CFI & $\geq 0,97$ & $\geq 0,95$ & 0,997 \\
GFI & $\geq 0,90$ & $089-0,85$ & 0,994 \\
AGFI & $\geq 0,90$ & $089-0,85$ & 0,961 \\
RMSEA & $\leq 0,05$ & $0,06-0,08$ & $\mathbf{0 , 0 8 5}$ \\
NFI & $\geq 0,95$ & $0,94-0,90$ & 0,996 \\
IFI & $\geq 0,95$ & $0,94-0,90$ & 0,997 \\
\hline
\end{tabular}

Modelde yer alan ifadelere ilişkin standardize regresyon yükleri Tablo 15'de yer almaktadır.

Tablo 15: Doğal Davranışa İlişkin Standardize Regresyon Yükleri

\begin{tabular}{clc}
\hline İfade Kısaltması & \multicolumn{1}{c}{ İfade } & $\begin{array}{c}\text { Standardize } \\
\text { Regresyon Yükleri }\end{array}$ \\
\hline DOĞ1 & Müşterilere karşı gösterdiğim duygular gerçek ve samimidir. & 0,928 \\
DOĞ2 & $\begin{array}{l}\text { Müşterilere karşı gösterdiğim duygular doğal bir şekilde gerçekleşir } \\
\text { DOĞ3 }\end{array}$ & $\begin{array}{l}\text { Müşterilere karşı gösterdiğim duygular hissettiğim duygular ile } \\
\text { örtüşür }\end{array}$ \\
\hline
\end{tabular}




\subsubsection{Doğal Davranışa İlişkin Güvenilirlik Analizi}

Doğal davranışa ilişkin iç tutarlılığı tespit etmek için Cronbach Alpha değerinden yararlanılmıştır. $\mathrm{Bu}$ doğrultuda doğal davranış ölçeğinin Cronbach Alpha değeri hesaplanmıştır. Doğal davranışın Cronbach Alpha değeri 0,919 olarak tespit edilmiştir. Doğal davranış ölçeğinin yüksek güvenilirliğe sahip olduğu söylenebilmektedir.

\subsection{Değişkenlere İlişkin Ortalama Değerler}

İşe yabancılaşma, algılanan sosyal destek ve doğal davranışa ilişkin ortalama değerler sırasıyla hesaplanmıştır. İşe yabancılaşmanın ortalama değeri 2,79, standart sapması ise 0,671'dir. Algılanan sosyal desteğin ortalama değeri 3,46, standart sapması ise 0,618 olarak hesaplanmıştır. Son olarak doğal davranışın ortalama değeri 3,52, standart sapması ise 0,907 olarak hesaplanmıştır. Ortalama değerlere göre işe yabancılaşma ortalama değerinin 3'den nispeten düşük olduğu tespit edilmiştir. Bu sonuca göre araştırma kapsamında işe karşı yabancılaşmanın çok yüksek olmadığı söylenebilmektedir. Algılanan sosyal destek ve doğal davranışa ilişkin ortalama değerlerin 3'den yüksek olduğu tespit edilmiştir. Bu sonuca göre çalışanların iş çevresinden sosyal destek alabildiği ve müşterilere karşı doğal davranış sergileyebildiği söylenebilmektedir.

\subsection{Algılanan Sosyal Destek İle İşe Yabancılaşma Arasındaki İlişkide Doğal Davranışın Aracılık Rolü}

SPSS PROCESS V3.2 makro programı yoluyla algılanan sosyal destek ile işe yabancılaşma arasındaki ilişkide doğal davranışın aracılık rolü test edilmiştir. Bu doğrultuda yapılan aracılık analizinin sonuçları Tablo 16'da yer almaktadır.

Tablo 16: Algılanan Sosyal Destek İle İşe Yabancılaşma Arasındaki İlişkide Doğal Davranışın Aracılık Rolüne

\begin{tabular}{lccc}
\multicolumn{4}{c}{ İlişkin Analiz Sonuçları } \\
\hline & \multicolumn{3}{c}{ İşe Yabancılaşma } \\
\hline & P Değeri & Toplam Etki & $\begin{array}{c}\text { Aracılık } \\
\text { (P Değeri) }\end{array}$ \\
\hline Algılanan Sosyal Destek & 0,005 & $-0,225$ & - \\
\hline Algılanan Sosyal Destek*Doğal Davranış & - & $-0,160$ & \\
\hline $\begin{array}{l}\text { Doğal davranışın işe yabancılaşma üzerindeki dolaylı etkisi: } \\
-\mathbf{0 , 0 6 5}\end{array}$ & & \\
BootLLCI Boot ULCI & & \\
$-0,1272-0,0105$ & & \\
\hline
\end{tabular}

Tablo 16'daki sonuçlara göre algılanan sosyal destek ile işe yabancılaşma arasındaki ilişkide doğal davranışın anlamlı bir kısmi aracılık etkisi bulunmaktadır ( $\mathrm{p}=0,007<0,050)$. Bootstrap güven aralığı değerleri 0 (sıfır)'ı kapsamamaktadır. Bu bulgu algılanan sosyal destek ile işe yabancılaşma arasındaki ilişkide doğal davranışın anlamlı bir kısmi aracılık etkisine sahip olduğunu kanıtlar niteliktedir. Algılanan sosyal destek ile işe yabancılaşma arasındaki ilişkide doğal davranışın aracılık rolü Şekil 11 'de gösterilmektedir. 


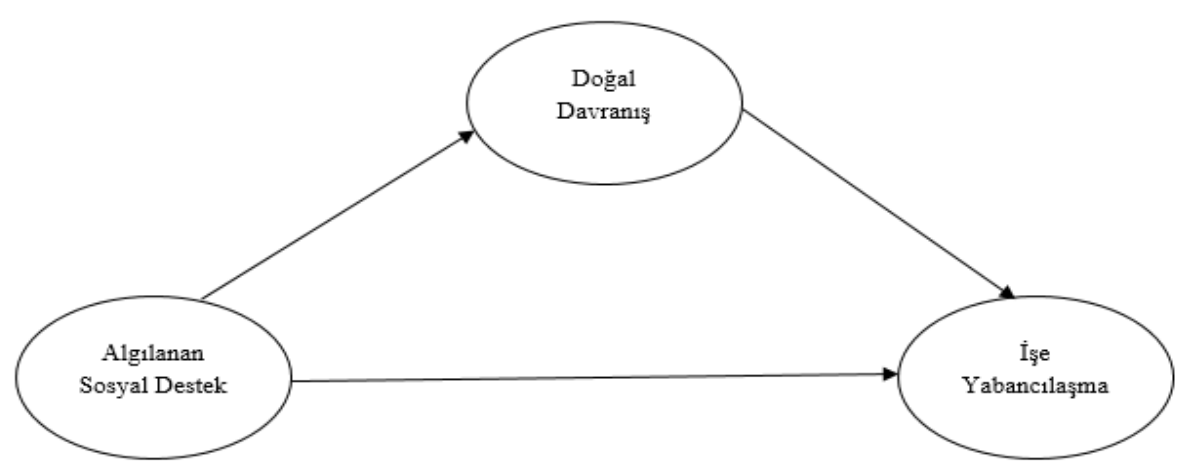

Şekil 11: Algılanan Sosyal Destek İle İşe Yabancılaşma Arasındaki İlişkide Doğal Davranışın Aracılık Rolü

Algılanan sosyal destek ile işe yabancılaşma arasındaki ilişkide doğal davranışın aracılık rolüne ilişkin yapılan analizler sonucunda doğal davranışın anlamlı bir şekilde aracılık rolü üstlendiği görülmektedir. Bu sonuçlara dayanarak algılanan sosyal desteğin işe yabancılaşma üzerinde anlamlı bir etkisinin bulunduğu ancak bu etki üzerinde esasında çalışanların doğal davranışs sergilemesinin payı olduğu ortaya çıkmıştır.

\section{Tartışma ve Sonuç}

Bu çalışmada bankacılık sektörünün gişe/operasyon bölümüne ilişkin olarak algılanan sosyal desteğin işe yabancılaşma üzerindeki etkisinde doğal davranışın aracılık etkisini ortaya koymak amaçlanmıştır. Aynı zamanda gişe/operasyon çalışanlarının algıladıkları sosyal destek, işe yabancılaşma ve doğal davranış düzeylerine ilişkin ortalama değerler de tespit edilmiştir. Bu doğrultuda ortalama değerlere bakıldığında gişe/operasyon çalışanlarının işe yabancılaşma düzeylerinin çok yüksek olmadığı tespit edilmiştir. Algılanan sosyal destek ortalamasına göre, gişe/operasyon çalışanlarının görev yaptıkları şubede genel olarak iş çevresinden destek alabildiğine yönelik bir sonuç ortaya çıkmaktadır. Bankacılık hizmetlerinin iş birliği içerisinde yürütülmesi ve riski azaltabilmek için bilgi ve fikir paylaşımının yoğun bir şekilde gerçekleştirilmesi çalışanların yakın iletişim kurmasına imkân verebilmektedir. Dolayısıyla zaman içerisinde gelişen iletişim neticesinde çalışanların birbirine destek vermesi beklenebilmektedir. Gişe/operasyon çalışanlarının doğal davranış düzeyinin de yüksek olduğu söylenebilmektedir. Bu sonuç gişe/operasyon çalışanlarının müşterilerle iletişim kurarken doğal ve içten davranış sergilediğine ve samimi duygularını müşterilere yansıttığına yönelik bilgi sunmaktadır. Genel ortalama değerler ışığında gişe/operasyon çalışanlarının düşük düzeyde sayılabilecek işe yabancılaşmanın sebebi olarak esasında çalışanların bankacılığın getirdiği stres ve zorluklar karşısında sosyal destek görebilmesi ve aynı zamanda tüm zorluklara rağmen duygularını düzenleyebilmesi ve empati kurabilmesi gösterilebilmektedir. Bununla birlikte gişe/operasyon çalışanlarının müşterilere karşı içten ve doğal olması ve sahte davranışlar sergilememesi çalışanlar üzerinde gerginlik yaratmadığı için işe karşı olumsuz bir tutum ortaya çıkmayabilmektedir. Bu 
açıklamalar araştırmanın örnekleminden elde edilen veriler ışı̆̆ında yapılmakta ve genelleme imkânı vermemektedir. Ortaya çıkan bu sonuçlar bölgesel olarak farklılık gösterebilmektedir. Dolayısıyla bu araştırma kapsamında elde edilen ortalama değerler farklı bölgelerde görev yapan gişe/operasyon çalışanları için değişik sonuçlar ortaya koyabilmektedir.

Araştırma modeli çerçevesinde algılanan sosyal desteğin işe yabancılaşma üzerindeki etkisinde doğal davranışın aracılık etkisi incelenmiştir. Araştırma kapsamında doğal davranışın algılanan sosyal destek ile işe yabancılaşma arasındaki ilişkide aracılık etkisine sahip olduğu tespit edilmiştir. Literatür incelemesi sonucunda algılanan sosyal desteğin işe yabancılaşma üzerindeki etkisine yönelik birçok çalışma bulunmakla birlikte (Nair \& Vohra, 2010; Mottaz, 1981; Pearlin, 1962; Korman, Wittig-Berman \& Lang, 1981; Banai \& Reisel, 2007), araştırma problemiyle ilişkili olabilecek başka çalışmalara ise rastlanmamıştır. Bu araştırma sonucunda da algılanan sosyal desteğin işe yabancılaşma üzerindeki etkisi görülmektedir. Ancak araştırmanın esas problemi olan doğal davranışın algılanan sosyal destek ile işe yabancılaşma arasındaki ilişkide aracı rol üstlenip üstlenmediğine yönelik literatürde başka çalışmalara rastlanmamıştır. Shankar ve Kumar (2014) gerçekleştirdiği bir çalışmada duygusal emek ile tükenmişlik arasındaki ilişkide sosyal desteğin düzenleyici etkisini kavramsal olarak açıklamıştır. Bu çalışmada duygusal emek stratejilerinden olan yüzeysel rol yapma davranışı ile derinden rol yapma davranışı incelenmiş ancak doğal davranış çalışma kapsamına alınmamıştır. Duygusal emek stratejilerinin tükenmişliği artırması ancak çalışanların sosyal desteğe sahip olması durumunda yüksek düzeyde bir artışın söz konusu olmayabileceğine dair görüş getirilmiştir. Her ne kadar bu çalışmada doğal davranış incelenmemiş olsa da, sosyal desteğin duygusal emek ile işe yabancılaşma gibi olumsuz bir kavram olan tükenmişlik arasındaki ilişkide düzenleyici etkiye sahip olabileceği dile getirilmiştir. Bu araştırma probleminde ise algılanan sosyal destek bağımsız değişken olarak incelenirken, duygusal emek stratejilerinden olan doğal davranış ise aracı değişken olarak ele alınmıştır. Dolayısıyla yapılan bu araştırmanın duygusal emek stratejilerinden olan doğal davranışın algılanan sosyal destek ile işe yabancılaşma arasındaki ilişkide aracılık rolünü üstlenmesi bakımından literatüre katkı sağlaması beklenmektedir.

Araştırmanın sonucuna göre algılanan sosyal desteğin alan işe yabancılaşma üzerinde anlamlı bir etkisi bulunmakla birlikte bu etkinin doğal davranıştan kaynaklandığı ifade edilebilmektedir. Gişe/ operasyon çalışanlarının iş çevresinden edindiği sosyal destek işe yabancılaşmanın azalmasında önemli olmakla birlikte, gişe/operasyon çalışanları müşterilere karşı doğal ve samimi duygularını yansıtamadığı takdirde algılanan sosyal desteğin işe yabancılaşma üzerindeki etkisi anlamsız hale gelebilmektedir. Buna göre iş çevresinden sosyal destek gören gişe/operasyon çalışanlarının işe karşı yabancılaşmaması için müşterilere karşı doğal ve samimi bir davranış sergilemesi gerektiği sonucuna ulaşılabilmektedir. Genel olarak araştırmaya yönelik bir değerlendirme yapıldığında işe yabancilaşmayı etkileyen birçok faktör bulunmakla birlikte bu çalışmada algılanan sosyal destek ve doğal davranış işe yabancılaşmayı etkileyen faktörler olarak ele alınmıştır. Dolayısıyla teorik çerçeveye uygun şekilde aracilık modeli oluşturulmuş ve test edilmiştir. Daha sonraki çalışmalara katkı sağlayabilmek için hem kültürel hem örgütsel bir değişken olan örgüt ikliminin ve yine örgütsel bir faktör olabilecek yönetim tarzının düzenleyici değişkenler olarak incelenmesi durumunda farklı sonuçların ortaya çıkabileceği tahmin edilmektedir. Bu araştırma bankacılık sektöründe yapılmış 
olup, şube yöneticilerinin şube çalışanları için oryantasyon çalışmaları düzenlemesi, çalışanlar ve yöneticiler arasında bütünlüğün, desteğin ve işbirliğinin sağlanmasına yönelik sosyal etkinliklerin, kamp çalışmalarının ve şubeler arası mini yarışmaların düzenlenmesi işe karşı yabancılaşmanın önüne geçebilecektir. Ayrıca şubelerin çalışanlarına yönelik katı ve eksiksiz duygu gösterim kurallarını uygulamaya koymak yerine, çalışanların hem müşterilerin hem de iş arkadaşlarının duygularını anlayabilmesi ve empati kurabilmesi adına duygusal zekâ atölyelerini ve farkındalık çalışmalarını işe alım aşamasında uygulamaya koyması işe karşı yabancılaşmayı azaltabilecektir.

\section{Yazar Katkısı}

$\mathrm{Bu}$ çalışma doktora tezinden üretilmiştir. Bu doğrultuda Selçuk YEKE literatür taramasını yapmış, araştırma verilerini toplamış ve analizleri gerçekleştirmiştir. İbrahim PINAR çalışmanın danışmanlığını yürütmüş olup, çalışmanın her aşamasında yapıcı yönlendirmelerde bulunmuş ve önemli katkılar sağlamıştır.

\section{Çıkar Çatışması}

Çalışmada yazarlar arasında çıkar çatışması yoktur.

\section{Finansal Destek}

Bu çalışma için herhangi bir kurumdan destek alınmamıştır.

\section{Kaynakça}

Abrahim, S., Mir, B. A., Suhara, H., Mohamed, F. A., \& Sato, M. (2019). Structural equation modeling and confirmatory factor analysis of social media use and education. International Journal of Educational Technology in Higher Education, 16(32), 1-25.

Ashforth, B. E., \& Humphrey, R. H. (1993). Emotional labor in service roles: The influence of identity. Academy of Management Review, 18(1), 88-115.

Aslan, H \& Mert, İ. S. (2019). Duygusal emek ile işe yabancılaşma ilişkisinde psikolojik sermayenin düzenleyici etkisi. Uluslararası Toplum Araştırmaları Dergisi (OPUS), 11(18), 1736-1772.

Banai, M., \& Reisel, W. D. (2007) The influence of supportive leadership and job characteristics on work alienation: A six-country investigation. Journal of World Business, 42, 463-476.

Banka şubelerinde çalışan sayısı azalıyor. Retrieved from https://www.capital.com.tr/finans/bankacilik/bankasubelerinde-calisan-sayisi-azaliyor

Begenirbaş, M. (2015). Psikolojik sermayenin çalışanların duygu gösterimleri ve işe yabancılaşmalarına etkileri: sağlık sektöründe bir araştırma. Süleyman Demirel Üniversitesi İktisadi ve İdari Bilimler Fakültesi Dergisi, 20(3), 249-263.

Diefendorff, J. M., Croyle, M. H., \& Gosserand, R. H. (2005). The dimensionality and antecedents of emotional labor strategies. Journal of Vocational Behavior, 66, 339-357.

Greenberg, E. S., \& Grunberg, L. (1995). Work alienation and problem alcohol behavior. Journal of Health and Social Behavior, 36(1), 83-102.

Gülaydın, M. (2019). Algılanan örgütsel destek ile duygusal emek davranışları arasındaki ilişki üzerine bir araştırma: Afyonkarahisar'daki beş yıldızlı otel işletmeleri örneği. (Yayınlanmamış Yüksek Lisans Tezi). Afyon Kocatepe Üniversitesi Sosyal Bilimler Enstitüsü, Afyon. 
Gülova, A. A., Palamutçuoğlu, B. T., \& Palamutçuoğlu, A. T. (2013). Duygusal emek ile işe bağlılık arasındaki ilişkide amir desteğinin rolü: Üniversitede öğrenci işleri personeline yönelik bir araştırma. Dokuz Eylül Üniversitesi İktisadi ve İdari Bilimler Fakültesi Dergisi, 28(2), 41-74.

Halis, M., \& Demirel, Y. (2016). Sosyal desteğin örgütsel soyutlama (dışlanma) üzerine etkisi. Kastamonu Üniversitesi İktisadi ve İdari Bilimler Fakültesi Dergisi, 11, 318-335.

Işık, M., \& Hamurcu, A. (2017). The role of job stress at emotional labor's effect on intention to leave: Evidence from call center employees. Business and Economic Horizons, 13(5), 652-665.

Hirschfeld, R. R., \& Field, H. S. (2000). Work centrality and work alienation: Distinct aspects of a general commitment to work. Journal of Organizational Behavior, 21, 789-800.

Hur, W. M., Moon, T. W., \& Jun, J. K. (2013). The role of perceived organizational support on emotional labor in the airline industry. International Journal of Contemporary Hospitality Management, 25(1), 105-123.

Karagöz, Y. (2016). SPSS ve AMOS 23 uygulamalı istatistiksel analizler. Nobel Yayınevi.

Kartal, M., \& Bardakçı, S. (2018). SPSS ve AMOS uygulamalı örneklerle güvenilirlik ve geçerlik analizleri. Akademisyen Kitabevi.

Kim, H. J., Hur, W. M., Moon, T.W., \& Jun, J. K. (2017). Is all support equal? the moderating effects of supervisor, coworker, and organizational support on the link between emotional labor and job performance. Business Research Quarterly, 20(2), 124-136.

Kitamura, T., Kijima, N., Watanabe, K., Takezakii, Y., \& Tanaka, E. (1999). Precedents of perceived social support: personality and early life experiences. Psychiatry and Clinical Neurosciences, 53, 649-654.

Korman, A. K., Wittig-Berman, U., \& Lang, D. (1981). Career success and personal failure: Alienation in professionals and managers. Academy of Management Journal, 24(2), 342-360.

Kökden, F. Ç., \& Işık, M. (2018). Çalışma hayatında duygusal emek ve işe yabancılaşma ilişkisi: Banka çalışanları üzerine bir uygulama. Süleyman Demirel Üniversitesi İktisadi ve İdari Bilimler Fakültesi Dergisi, 23(4), 1215-1237.

Köse, G. (2019). Duygusal emek faktörünün hizmet kalitesi ve işe yabancılaşma üzerindeki etkisi. (Yayınlanmamış Yüksek Lisans Tezi). Marmara Üniversitesi Sosyal Bilimler Enstitüsü, İstanbul.

Lee, D. C., Hung, L. M., \& Huang, S. C. (2012). Does job enjoyment and organizational support affect emotional labor?, Journal of Business Research-Türk, 4(2), 5-29.

Meydan, C. H., \& Şeşen, H. (2015). Yapısal eşitlik modellemesi: AMOS uygulamaları. Detay Yayıncılık.

Mikeska, J., Hamwi, G. A., Friend, S. B., Rutherford, B. N., \& Park, J. (2015). Artifical emotions among salespeople: understanding the impact of surface acting. The Marketing Management Journal, 25(2), 54-70.

Mottaz, C. J. (1981). Some determinants of work alienation. The Sociological Quarterly, 22(4), 515-529.

Nair, N., \& Vohra, N. (2010). An exploration of factors predicting work alienation of knowledge workers. Management Decision, 48(4), 600-615.

Oktuğ, Z. (2013). Algılanan örgütsel destek ile duygusal emek davranışları arasındaki ilişkide algılanan örgütsel prestijin biçimlendirici etkisi. Elektronik Sosyal Bilimler Dergisi, 12(46), 370-381.

Oral, L., \& Köse, S. (2011). Hekimlerin duygusal emek kullanımı ile iş doyumu ve tükenmişlik düzeyleri arasındaki ilişkiler üzerine bir araştırma. Süleyman Demirel Üniversitesi İktisadi ve İdari Bilimler Fakültesi Dergisi, 16(2), 463-492.

Payne, T. J., Andrew, M., Butler, K. R., Wyatt, S. B., Dubbert, P. M., \& Mosley, T. H. (2012). Psychometric evaluation of the interpersonal support evaluation list-short form in the aric study cohort. SAGE Open, 2(3), $1-8$.

Pearlin, L. I. (1962). Alienation from work: A study of nursing personnel. American Sociological Review, 27(3), 314-326. 
Peart, F. M., Roan, A. M., \& Ashkanasy, N. M. (2012). Trading in emotions: A closer examination of emotional labor experiencing and managing emotions in the workplace, Ashkanasy, N. M., Härtel, C. E. J., \& Zerbe, W. J (Eds.). Emerald Group Publishing Limited, Bingley.

Schaefer, C., Coyne, J. C., \& Lazarus, R. S. (1981). The health-related functions of social support. Journal of Behavioral Medicine, 4(4), 381-406.

Schermelleh-Engel, K., Moosbrugger, H., \& Müller, H. (2003). Evaluating the fit of structural equation models: Tests of significance and descriptive goodness of fit measures. Methods of Psychological Research, 8(2), 23-74.

Seçer, H. Ş. (2010). Çalışma yaşamında duygular ve duygusal emek: sosyoloji, psikoloji ve örgüt teorisi açısından bir değerlendirme. Sosyal Siyaset Konferansları Dergisi, 50, 813-834.

Shankar, B \& Kumar, S. (2014). Emotional labour and burnout relationship: Role of social support and coping. Indian Journal of Community Psychology, 10(2), 263-277.

Shantz, A., Alfes, K., Bailey, C., \& Soane, E. (2015). Drivers and outcomes of work alienation: Reviving a concept. Journal of Management Inquiry, 24(4), 283-393.

Türkiye Bankalar Birliği. Banka ve Şube Bilgileri. Retrieved from https://www.tbb.org.tr/tr/bankacilik/bankave-sektor-bilgileri/banka\%20bilgileri/.

Türkiye Bankalar Birliği (2019). Bankacılık Sisteminde Banka, Çalışan ve Şube Sayıları. TBB Mart Raporu, Rapor Kodu: DT13.

Tekingündüz, S., Kurtuldu, A., \& Eğilmez, Ç. (2016). Sosyal destek, işe yabancılaşma ve iş stresinin işgören performansı üzerindeki etkisinin incelenmesi. International Journal of Human Sciences, 13(1), 683-694.

Wu, X., Shie, A. J., \& Gordon, D. (2017). Impact of customer orientation on turnover intention: Mediating role of emotional labour. International Journal of Organizational Analysis, 25(5), 909-927.

Yıldırım, İ. (1997). Algılanan sosyal destek ölçeğinin geliştirilmesi güvenirliği ve geçerliği. Hacettepe Üniversitesi Eğitim Fakültesi Dergisi, 13, 81-87.

Yıldız, D., \& Uzunsakal, E. (2018). Alan araştırmalarında güvenilirlik testlerinin karşılaştırılması ve tarımsal veriler üzerine bir uygulama. Uygulamalı Sosyal Bilimler Dergisi, 1, 14-28.

\section{Özgeçmiş}

Selçuk YEKE (Dr.), 2011 yılında İstanbul Üniversitesi İşletme Fakültesi’nden mezun olmuştur. İstanbul Üniversitesi'nde işletme yönetimi ve organizasyon alanında yüksek lisansını ve doktorasını tamamlamış olup, şu anda Ardahan Üniversitesi İktisadi ve İdari Bilimler Fakültesi'nde araştırma görevlisi doktor olarak görev yapmaktadır. İşletme yönetimi, stratejik yönetim ve örgütsel davranış başlıca çalışma alanlarını oluşturmaktadır.

İbrahim PINAR (Prof. Dr.), 1985 yllında İstanbul Teknik Üniversitesi makine mühendisliği bölümünden mezun olmuştur. İstanbul Üniversitesi’nde organizasyon ve işletme politikası alanında yüksek lisansını ve doktorasını tamamlamış olup, şu anda İstanbul Üniversitesi İşletme Fakültesỉnde profesör olarak görev yapmaktadır. İşletme yönetimi, stratejik yönetim, teknoloji yönetimi ve bilgi temelli organizasyonlar başlıca çalışma alanlarını oluşturmaktadır. 